Printed ISSN : $2406-7415$

Electronic ISSN : $2655-9919$

DOI: http://dx.doi.org/10.35137/jabk.v8i2.542 Volume 8 No. 2 (Mei - Agustus) 2021

\title{
PENGARUH LIKUIDITAS, LEVERAGE, DAN \\ PERTUMBUHAN PERUSAHAAN TERHADAP PROFITABILITAS \\ (STUDI EMPIRIS PADA PERUSAHAAN MANUFAKTUR \\ SUB SEKTOR MAKANAN DAN MINUMAN YANG TERDAFTAR \\ DI BURSA EFEK INDONESIA TAHUN 2015-2019)
}

\author{
Aryo Bagaskoro ${ }^{1}$ \\ ${ }^{1}$ Fakultas Ekonomi Universitas Krisnadwipayana \\ Jalan Unkris Jatiwaringin Jakarta Timur \\ Email: aryobagaskoro5@gmail.com \\ Mulia Rahmah ${ }^{2}$ \\ ${ }^{2}$ Fakultas Ekonomi Universitas Krisnadwipayana \\ Jalan Unkris Jatiwaringin Jakarta Timur \\ e-mail: muliarahmah@gmail.com
}

\begin{abstract}
The research to test empirically the effect of Liquidity, Leverage, and Company's Growth on Profitability of Manufacturing Companies in the Food and Beverages Sector Listed on the Indonesia Stock Exchange on 2015-2019. The research was conducted in food and beverage sector manufacturing companies listed on the Indonesia Stock Exchange (BEI) in the 20152019 period. The sampling method used was purposive sampling method, the sample used was 17 companies. The data analysis technique used is descriptive statistics, classic assumption test, normally test, multicolonierity test, autocorrelation test, heteroscedasticity test, multiple liner regression model and hypothesis testing using SPSS 24 for windows. The result showed that Liquidity, Leverage, and Company's Growth has simultaneously affect Profitability. In Parsial, Liquidity has a positive and significant effect on Profitability. Meanwhile, Leverage has a negative but insignificant effect on Profitability. And Company's Growth has a positive and significant effect on Profitability.
\end{abstract}

Keywords: Liquidity, Leverege, Growth, Profitability

\section{PENDAHULUAN}

Profitabilitas merupakan kemampuan usaha perusahaan dalam menghasilkan laba dengan seluruh aktiva atau modal yang dimilikinya (Sartono 2010). Profitabilitas dapat menunjukkan apakah perusahaan tersebut memiliki prospek yang baik atau tidak (Novyanny and Turangan 2013). Tingkat profitabilitas mencerminkan kemampuan modal perusahaan dalam memperoleh keuntungan, dengan tingkat profitabilitas yang tinggi dapat mencerminkan efisien yang tinggi (Susanto and Kholis 2016). Apabila perusahaan memiliki laba yang besar, maka dapat dikatakan perusahaan memiliki kinerja yang baik, dan maupun sebaliknya, jika laba yang diperoleh perusahaan tersebut kecil dari periode sebelumnya, dapat disimpulkan bahwa 
DOI: http://dx.doi.org/10.35137/jabk.v8i2.542

perusahaan memiliki kinerja yang kurang baik.

Rasio profitabilitas merupakan rasio yang menunjukkan keberhasilan perusahaan didalam menghasilkan keuntungan (Lusiana 2010). Rasio profitabilitas sering disebut sebagai rentabilitas ekonomis, yang diartikan dengan ukuran kemampuan perusahaan dalam menghasilkan laba atas aktiva yang dimiliki perusahaan tersebut. Alat ukur yang digunakan dalam mengukur tingkat profitabilitas, antara lain gross profit margin (GPM), net profit margin (NPM), return on assets (ROA), return on equity (ROE), dan operating (OPM). Dalam penelitian ini peneliti menggunakan indikator return on assets (ROA) sebagai proksi dari profitabilitas. return on assets (ROA) merupakan alat ukur kemampuan perusahaan menghasilkan laba dari total aktiva yang digunakan (Hikmatullah 2017). Semakin tinggi return on assets, maka semakin efesien dan efektif pengelolaan asset perusahaan dan menunjukan semakin tinggi profitabilitas perusahaan (Tandelilin 2010). Alasan penelitian ini menggunakan return on assets sebagai alat untuk mengukur profitabilitas, karena rasio ini mencerminkan seberapa banyak perolehan yang dihasilkan perusahaan atas seluruh sumber daya keuangan yang ditanamkan pada perusahaan itu tersebut (Nugroho and Pangestuti 2011).

Likuiditas merupakan ukuran yang menunjukan kemampuan perusahaan dalam memenuhi semua kewajiban hutang-hutang jangka pendeknya (Wahyudi 2015). Jika perusahaan dapat membayar hutangnya maka perusahaan dinilai sebagai perusahaan yang liquid (lancar). Makin tinggi likuiditas, maka semakin baiklah posisi dimata
Printed ISSN : $2406-7415$

Electronic ISSN : 2655 - 9919

Jurnal Akuntansi dan Bisnis Krisnadwipayana Volume 8 No. 2 (Mei - Agustus) 2021

kreditur. Karena terdapat kemungkinan jika perusahaan akan dapat membayar kewajiban tepat pada waktunya (Andre 2010). Ada beberapa faktor yang harus diperhatikan oleh manajemen dalam rangka mengatur masalah likuiditas secara efisien, diantaranya: faktor yang berhubungan dengan biaya yang harus dikeluarkan oleh perusahaan jika menggunakan dana diluar operasional (cost of external financing), ketidakpastian arus kas yang diterima perusahaan (cash flow uncertainty), kesempatan investasi yang dimiliki perusahaan baik saat ini maupun diwaktu yang akan datang (current future investment opportunities), dan kebutuhan kas untuk transaksi (transaction demand for liquidity). Masalah likuditas biasanya berhubungan dengan masalah kemampuan suatu perusahaan dapat memenuhi kewajiban atau hutang keuangannya yang harus dipenuhi. Suatu perusahaan yang sudah memiliki kekuatan untuk membayar belum tentu dapat memenuhi seluruh keuangannya yang harus dipenuhi (Afrinda Nidya 2013). Salah satu alat yang digunakan untuk mengukur tingkat likuiditas suatu perusahaan, diantaranya rasio lancar (Current Ratio), rasio sangat lancar (Quick Ratio), rasio kas (Cash Ratio), dan rasio perputaran kas (Cash Turnover). Dalam penelitian ini peneliti menggunakan indikator rasio lancar (Current Ratio) sebagai proksi dari likuiditas.

$\begin{array}{ccc}\text { Rasio lancar } & \text { (Current Ratio) } \\ \text { merupakan } & \text { rasio untuk mengukur }\end{array}$ kemampuan perusahaan dalam membayar kewajiban jangka pendek atau utang yang segera jatuh tempo pada saat ditagih secara keseluruhan (Kasmir 2016). Current ratio atau rasio lancar merupakan ukuran dari likuiditas yang berjangka pendek, atau perbandingan antara asset lancar dengan 
DOI: http://dx.doi.org/10.35137/jabk.v8i2.542

kewajiban lancar (Afrinda 2013). Current Ratio merupakan indicator yang sesungguhnya dari likuiditas perusahaan, karena rasio ini memperhitungkan pertimbangan hubungan yang relatif antara aktiva lancar dengan hutang lancar setiap perusahaan. Current ratio digunakan sebagai alat mengukur likuiditas suatu perusahaan, dan juga merupakan petunjuk untuk dapat mengetahui suatu perusahaan mampu untuk memenuhi kewajiban keuangannya. Current ratio yang rendah lebih banyak memiliki resiko daripada suatu current ratio yang tinggi. Namun terkadang suatu current ratio yang rendah malahan menunjukkan pimpinan suatu perusahaan tersebut menggunakan aktiva lancar dengan efektif. Perusahaan dengan current ratio yang tinggi bukan merupakan jaminan bahwa perusahaan mampu membayar kewajibannya yang sudah jatuh tempo karena proporsi atau distribusi dari aktiva lancar yang menguntungkan (Nugroho 2011).

Leverage merupakan penggunaan asset dan sumber dana (sources of funds) oleh perusahaan yang memiliki biaya tetap (beban tetap) dengan maksud agar meningkatkan keuntungan pemegang saham (Wahyudi 2015). Leverage dapat digunakan untuk meningkatkan hasil pengembalian pemegang saham, namun dengan resiko yang akan meningkatkan kerugian. Apabila proporsi leverage tidak diperhatikan, bisa terjadi profitabilitas perusahaan akan menurun, karena penggunaan hutang dapat menimbulkan beban bunga yang bersifat tetap (Putra and Badjra 2015). Untuk itu menghitung besarnya penggunaan hutang perusahaan dapat menggunkan beberapa rasio leverage antara lain debt assets ratio (DAR), debt equity ratio (DER), equity multiper (EM), dan interest coverage (IC) atau times
Printed ISSN : $2406-7415$

Electronic ISSN : 2655 - 9919

Jurnal Akuntansi dan Bisnis Krisnadwipayana Volume 8 No. 2 (Mei - Agustus) 2021

interest earned (TIE). Penelitian ini diproksikan pada debt to equity ratio (DER). Debt to equity ratio (DER) merupakan rasio yang digunakan untuk menghitung utang serta modal yang berguna untuk menutupi utang-utang kepada pihak luar (PA and Dohar 2016). Alasan penelitian ini menggunakan debt to equity ratio, karena debt to equity ratio dapat mengukur seberapa besar total aktiva yang dimiliki oleh perusahaan yang dibiayai dengan menggunakan hutang. Penggunaan hutang dalam kegiatan pendanaan perusahaan tidak hanya memberikan dampak baik terhadap perusahaan, namun apabila proporsi debt to ratio tidak diperhatikan oleh perusahaan tersebut maka akan menyebabkan turunnya profitabilitas karena penggunaan hutang menimbulkan beban bunga yang bersifat tetap (PA and Dohar 2016). Debt to equity ratio (DER) dapat menunjukkan kemampuan perusahaan dalam membayar hutang jangka panjang.

Pertumbuhan perusahaan (Growth) merupakan sebuah ukuran seberapa jauh perusahaan menempatkan diri dalam sistem ekonomi secara keseluruhan atau sistem ekonomi dalam perusahaan (Aryanti et al. 2017). Perusahaan akan tumbuh dengan cepat memperoleh hasil positif apabila melakukan strategi yang benar di era persaingan, menikmati penjualan yang meningkat secara signifikan. Tingkat pertumbuhan perusahaan akan menggunakan hutang sebagai sumber pembiayaan perusahaan tersebut. Dalam hubungannya dengan leverage, perusahaan dengan tingkat pertumbuhan yang tinggi sebaiknya menggunakan ekuitas sebagai sumber pembiayaannya, alasannya agar tidak terjadi biaya keagenan (agency cost) antara pemegang saham dengan manajemen 
DOI: http://dx.doi.org/10.35137/jabk.v8i2.542

perusahaan, sebaliknya perusahaan dengan tingkat pertumbuhan yang rendah sebaiknya menggunakan hutangnya dengan baik sebagai sumber pembiayaan karena penggunaan hutang akan mengharuskan perusahaan tersebut membayar buang secara teratur (Kusumajaya 2011). Agar pertumbuhan perusahaan tidak memiliki arti pertumbuhan biaya yang kurang terkendali, maka dalam mengelola pertumbuhan, perusahaan harus memiliki pengendalian operasi dengan penekanan pada pengendalian biaya (Susanto 1997).

Sektor Industri Manufaktur makanan dan minuman merupakan salah satu sektor yang mampu bertahan dalam kondisi perekonomian Indonesia yang sedang tidak pasti, dan karena masyarakat tetap membutuhkan produk makanan dan minuman (Sari and Abudanti 2014). Meningkatnya permintaan konsumen terhadap produk manufaktur industri makanan dan minuman mengakibatkan setiap perusahaan memiliki kemampuan manajemen yang baik agar perusahaan mendapatkan profit yang besar. Setiap perusahaan manufaktur memiliki strategi demi meningkatkan penjualannya, sehingga produk yang dihasilkan mampu menarik minat konsumen. Meningkatnya penjualan produk yang dihasilkan maka meningkatkan pula profitabilitas perusahaan.

\section{LANDASAN TEORI}

\section{Laporan Keuangan}

Pengertian Laporan Keuangan menurut PSAK No.1 adalah sebagai berikut: "Laporan keuangan adalah bagian dari proses pelaporan keuangan yang lengkap yang biasanya meliputi neraca,
Printed ISSN : $2406-7415$

Electronic ISSN : 2655 - 9919

Jurnal Akuntansi dan Bisnis Krisnadwipayana Volume 8 No. 2 (Mei - Agustus) 2021

laporan laba rugi, laporan perubahan posisi keuangan yang dapat disajikan dalam berbagai cara seperti misalnya sebagai laporan arus kas, atau laporan arus dana, catatan dari laporan lain serta materi penjelasan yang merupakan bagian integral dari laporan keuangan." Sedangkan menurut (Sundjaja et al. 2001) adalah sebagai berikut: "Laporan keuangan adalah suatu laporan yang menggambarkan hasil dari proses akuntansi yang digunakan sebagai alat komunikasi bagi pihak-pihak yang berkepentingan dengan data keuangan atau aktivitas perusahaan."

\section{Rasio Keuangan}

Pengertian Rasio Keuangan menurut (Munawir 2015) mengemukakan bahwa: "Rasio Keuangan adalah future oriented atau berorientasi dengan masa depan, artinya bahwa dengan analisa ratio keuangan dapat digunakan sebagai alat untuk meramalkan keandaan keuangan serta hasil usaha dimasa mendatang."

Menurut

(Samryn

2011)

mendefinisikan Rasio Keuangan sebagai berikut: "Suatu cara yang membuat perbandingan data keuangan perusahaan menjadi lebih arti. Rasio keuangan menjadi dasar untuk menjawab beberapa pertanyaan penting mengenai kesehatan keuangan dari perusahaan."

\section{Likuiditas (Liquidity)}

Pengertian Rasio Likuiditas menurut (Kasmir 2016) mengemukakan: "Likuiditas (liquidity ratio) merupakan rasio yang menggambarkan atau mengukur kemampuan perusahaan dalam memenuhi kewajiban (hutang) jangka pendek. Artinya apabila perusahaan ditagih, perusahaan akan mampu untuk memenuhi 
DOI: http://dx.doi.org/10.35137/jabk.v8i2.542

hutang tersebut terutama hutang yang sudah jatuh tempo." Sedangkan, menurut (Brigham and F.Houston 2013): "Aset likuid merupakan asset yang diperdagangkan di pasar aktif sehingga dapat dikonversi dengan cepat menjadi kas pada harga pasar yang berlaku, sedangkan posisi likuidiras suatu perusahaan berkaitan dengan pertanyaan, apakah perusahaan mampu melunasi hutangnya ketika hutang tersebut jatuh tempo ditahun berikutnya."

Namun menurut (Sartono 2010) mengatakan bahwa: "Rasio Likuiditas menunjukkan kemampuan untuk membayar kewajiban keuangan jangka pendek tepat pada waktunya."

\section{Leverage}

Pengertian Rasio Leverage menurut (Sartono 2010) mengemukakan bahwa: "Leverage merupakan penggunaan asset dan sumber dana oleh perusahaan yang memiliki biaya tetap (beban tetap) dengan maksud agar meningkatkan keuntungan potensial pemegang saham" Sedangkan pengertian Rasio Leverage menurut (Tjiptono and Fakhruddin 2011) menjelaskan bahwa: "Leverage merupakan jumlah utang yang digunakan untuk membiayai atau membeli aser-aset perusahaan. Perusahaan yang memiliki hutang lebih besar dari equity dikatakan sebagai perusahaan dengan tingkat leverage yang tinggi."

$+$

\section{Pertumbuhan Perusahaan (Growth)}

Pengertian Pertumbuhan Perusahaan menurut (Fauzi and Suhadak 2015) menyatakan bahwa: "Setiap perusahaan berusaha mencapai pertumbuhan yang tinggi setiap tahunnya karena pertumbuhan perusahaan memberikan gambaran
Printed ISSN : $2406-7415$

Electronic ISSN : 2655 - 9919

Jurnal Akuntansi dan Bisnis Krisnadwipayana Volume 8 No. 2 (Mei - Agustus) 2021

perkembangan yang terjadi diperusahaan." Sedangkan menurut (Adibah 2013) menyatakan bahwa: "Pertumbuhan Perusahaan merupakan kemampuan perusahaan dalam meningkatkan asset perusahaan. Pertumbuhan perusahaan menggambarkan tingkat ekspansi yang diusahakan oleh perusahaan dengan melihat pertumbuhan aktiva yang digunakan dalam kegiatan operasional."

\section{Profitabilitas (Profitability)}

Pengertian Profitabilitas menurut (Simamora 2000) sebagai berikut: "Proses untuk menentukan seberapa baik aktivitas-aktivitas bisnis dilaksanakan untuk mencapai tujuan strategis, mengeliminasi pemborosan-pemborosan dan menyajikan informasi yang tepat waktu untuk melaksanakan penyempurnaan secara berkesinambungan. Dengan demikian bagi investor jangka panjang akan sangat berkepentingan dengan analisa profitabilitas ini." Sedangkan menurut (Sartono 2010) mengatakan bahwa: "Profitabilitas adalah kemampuan perusahaan mempoleh laba dalam hubungannya dengan penjualan, total aktiva maupun modal sendiri."

\section{METODE PENELITIAN}

Teknik untuk mencari, mengumpulkan dan memperoleh data berupa data primer ataupun sekunder dapat digunakan untuk menyusun sebuah karya ilmiah dan kemudian menganalisis faktor-faktor yang memiliki hubungan dengan pokok permasalahan sehingga didapatkan suatu kebenaran data, merupakan dari metode penelitian.

Objek penelitian yang sudah ditetapkan oleh peneliti sesuai dengan 
DOI: http://dx.doi.org/10.35137/jabk.v8i2.542

pemasalahan yang akan diteliti yaitu dilakukan pada Perusahaan Manufaktur Sub Sektor Makanan dan Minuman yang terdaftar di Bursa Efek Indonesia (BEI) periode 2015-2019, sebanyak tiga puluh satu perusahaan.

Desain penelitian ini adalah jenis penelitian kuantitatif yang menurut tingkat eksplanasinya termasuk penelitian asosiatif dengan pendekatan kasual. Menurut (Sugiyono 2016) penelitian asosiatif merupakan penelitian yang bertujuan untuk mengetahui pengaruh dua variabel atau lebih.

Jenis data yang digunakan merupakan data sekunder atau berupa data kuantitatif dengan sumber data dari laporan keuangan yang telah diaudit Perusahaan Manufaktur Sub Sektor Makanan dan Minuman yang Terdaftar di Bursa Efek Indonesia (BEI) yang merupakan data time series periode tahun 2015 sampai dengan tahun 2019 diperoleh dari website idx.co.id.

Variabel didalam penelitian ini terdiri dari variable independen atau variable bebas. Variabel independen yang digunakan dalam penelitian ini adalalah Likuiditas yang diproksikan dari Current Ratio, Leverage diproksikan dengan Debt to Equity Ratio, dan Pertumbuhan Perusahaan yang diproksikan dengan Growth. Dan Variable dependent (variabel terikat) yaitu variabel yang dipengaruhi oleh variabel lain.

Populasi dari penelitian ini adalah tiga puluh satu perusahaan manufaktur sektor makanan dan minuman selama periode pengamatan dari tahun 2015 sampai dengan 2019 jumlah sampel yang dipilih dalam penelitian ini menggunakan purposive sampling.

Data yang digunakan adalah data sekunder yang diperoleh melalui Indonesia Stox Exchange atau Bursa Efek Indinesia yang dipublikasikan di situs resminya
Printed ISSN : $2406-7415$

Electronic ISSN : 2655 - 9919

Jurnal Akuntansi dan Bisnis Krisnadwipayana Volume 8 No. 2 (Mei - Agustus) 2021

idx.co.id, yaitu laporan keuangan perusahaan industri manufaktur sub sektor makanan dan minuman yang listing di Bursa Efek Indonesia (BEI) tahun 2015-2019.

Alasan penelitian ini menggunakan purposive sampling adalah karena tidak semua sampel memiliki kriteria yang sesuai dengan yang peneliti tentukan, oleh karena itu peneliti memilih teknik purposive sampling.

Instrument penelitian merupakan alat ukur yang digunakan untuk mendapatkan suatu informasi, dan sebagai alat bantu untuk mengumpulkan data agar penelitian yang dilakukan menjadi mudah dan sistematis. Dalam penelitian ini instrument penelitian yang digunakan yaitu data sekunder yang berupa laporan keuangan tahunan pada perusahaan yang sudah menyampai laporan keuangansecara terus-menerus selama periode tahun 2015 - 2019, perusahaan yang akan diteliti yaitu Perusahaan Manufaktur Subsektor Makanan dan Minuman yang terdaftar di Bursa Efek Indonesia (BEI).

Pengumpulan data merupakan suatu proses pengadaan data primer dan data sekunder untuk keperluan penelitian.

Teknik pengumpulan data pada penelitian ini dilakukan untuk menghasilkan kesimpulan sesuai dengan perumusahan masalah, maka teknik pengumpulan data adalah dokumentasi data dengan penggunaan data sekunder.

\section{HASIL DAN PEMBAHASAN}

\section{Analisis Statistik Deskriptif}

Analisis statistik deskritif digunakan untuk memberikan deskripsi tentang data setiap variable variable penelitian yang digunakan di dalam penelitian ini. 
Data tersebut meliputi jumlah data, nilai minimum, nilai maksimum, nilai rata-rata (mean), dan standar deviasi. Penelitian ini menggunakan variable likuditias, leverage, dan pertumbuhan perusahaan sebagai variable independen, serta profitabilitas sebagai variable dependen. Pada bagian ini akan disajikan deskripsi data yang diperoleh dari data yang telah diolah dengan program SPSS (Statistical Package For Social Science) Version 24 For Windows meliputi tabel distribusi frekuensi dari variable yang dipilih peneliti.

Tabel 1 Hasil Uji Deskriptif Statistik Sumber: Data diolah oleh peneliti, 2020

\begin{tabular}{|c|c|c|c|c|c|}
\hline \multicolumn{6}{|c|}{ Descriptive Statistics } \\
\hline & $\mathrm{N}$ & Minimum & Maximum & Mean & $\begin{array}{c}\text { Std. } \\
\text { Deviation }\end{array}$ \\
\hline Likuiditas & 59 & .45 & 4.19 & 1.7529 & .80280 \\
\hline Leverage & 59 & .04 & 1.95 & .8873 & .44876 \\
\hline $\begin{array}{l}\text { pertumbuhan } \\
\text { perusahaan }\end{array}$ & 59 & -.14 & .32 & .0803 & .10349 \\
\hline Profitabilitas & 59 & -.07 & .18 & .0577 & .06003 \\
\hline $\begin{array}{l}\text { Valid N } \\
\text { (listwise) }\end{array}$ & 59 & & & & \\
\hline
\end{tabular}

Berdasarkan tabel 1 diatas diketahui bahwa terdapat empat variable penelitian yaitu Likuiditas, Leverage, Pertumbuhan Perusahaan (Growth) dan Profitabilitas yang digunakan dalam penelitian ini. Jumlah $\mathrm{N}$ yaitu jumlah seluruh sampel yang diteliti.

\section{Variabel Likuiditas (X1) Pada Perusahaan Manufaktur Sektor Industri Makanan dan Minuman Pada Tahun 2015-2019}

Berdasarkan hasil perhitungan tabel 1 pada variabel likuiditas menggunakan software SPSS versi 24 menganalisi data hasil hitungan Current Ratio (CR):

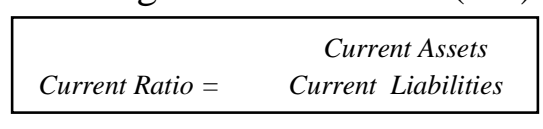

Pada variabel ini memiliki nilai minimum 0,45, nilai maksimum 4,19, mean 1,7529, dengan nilai standar deviasi 0,80280 dan dengan jumlah pengamatan sebanyak 59 perusahaan. Likuiditas dapat digunakan dalam mengukur seberapa mampu perusahaan untuk membayar utang jangka pendeknya. Semakin lancar perusahaan dalam memenuhi kebutuhan jangka pendeknya, maka perusahaan dapat dikatakan perusahaan yang liquid. (Lely 2019).

Tabel 2 Likuditas Pada Perusahaan Manufaktur Sub Sektor Makanan dan Minuman Pada Tahun 2015-2019

Copyright (c) 2021 Mulia Rahmah, S. Kom., M.Si., Aryo Bagaskoro 


\begin{tabular}{|c|c|c|c|}
\hline No & Tahun & Nama Perusahaan & $\begin{array}{l}\text { Likuid } \\
\text { itas }\end{array}$ \\
\hline 1 & 2015 & Akasha Wira Internasional Tbk & 1.39 \\
\hline 2 & 2016 & Akasha Wira Internasional Tbk & 1.64 \\
\hline 3 & 2017 & Akasha Wira Internasional Tbk & 1.2 \\
\hline 4 & 2018 & Akasha Wira Internasional Tbk & 1.39 \\
\hline 5 & 2019 & Akasha Wira Internasional Tbk & 0.45 \\
\hline 6 & 2015 & Tiga Pilar Sejahtera Food Tbk & 1.62 \\
\hline 7 & 2016 & Tiga Pilar Sejahtera Food Tbk & 2.38 \\
\hline 8 & 2015 & Budi Starch Sweetener Tbk & 1 \\
\hline 9 & 2016 & Budi Starch Sweetener Tbk & 1 \\
\hline 10 & 2017 & Budi Starch Sweetener Tbk & 1.01 \\
\hline 11 & 2018 & Budi Starch Sweetener Tbk & 1 \\
\hline 12 & 2019 & Budi Starch Sweetener Tbk & 1.01 \\
\hline 13 & 2017 & Bumi Teknokultura Unggul Tbk & 1.01 \\
\hline 14 & 2018 & Bumi Teknokultura Unggul Tbk & 2.15 \\
\hline 15 & 2019 & Bumi Teknokultura Unggul Tbk & 1.75 \\
\hline 16 & 2015 & Cahaya Kalbar Tbk & 1.53 \\
\hline 17 & 2016 & Cahaya Kalbar Tbk & 2.19 \\
\hline 18 & 2017 & Cahaya Kalbar Tbk & 2.22 \\
\hline 19 & 2015 & Indofood CBP Sukses Makmur TBK & 2.33 \\
\hline 20 & 2016 & Indofood CBP Sukses Makmur TBK & 2.41 \\
\hline 21 & 2017 & Indofood CBP Sukses Makmur TBK & 2.43 \\
\hline 22 & 2018 & Indofood CBP Sukses Makmur TBK & 1.95 \\
\hline 23 & 2019 & Indofood CBP Sukses Makmur TBK & 2.54 \\
\hline 24 & 2015 & Inti Agri Resources Tbk & 1.01 \\
\hline 25 & 2016 & Inti Agri Resources Tbk & 0.68 \\
\hline 26 & 2017 & Inti Agri Resources Tbk & 0.82 \\
\hline 27 & 2018 & Inti Agri Resources Tbk & 0.95 \\
\hline 28 & 2015 & Indofood Sukses Makmur Tbk & 1.71 \\
\hline 29 & 2017 & Indofood Sukses Makmur Tbk & 1.52 \\
\hline 30 & 2018 & Indofood Sukses Makmur Tbk & 1.07 \\
\hline 31 & 2019 & Indofood Sukses Makmur Tbk & 1.27 \\
\hline 32 & 2016 & Kino Indonesia Tbk & 1.54 \\
\hline 33 & 2017 & Kino Indonesia Tbk & 1.65 \\
\hline 34 & 2018 & Kino Indonesia Tbk & 1.5 \\
\hline 35 & 2019 & Kino Indonesia Tbk & 1.35 \\
\hline 36 & 2015 & Mayora Indah Tbk & 2.37 \\
\hline 37 & 2016 & Mayora Indah Tbk & 2.25 \\
\hline 38 & 2017 & Mayora Indah Tbk & 2.39 \\
\hline 39 & 2018 & Mayora Indah Tbk & 2.65 \\
\hline 40 & 2019 & Mayora Indah Tbk & 3.43 \\
\hline 41 & 2015 & Prasidha Aneka Niaga Tbk & 1.1 \\
\hline 42 & 2016 & Prasidha Aneka Niaga Tbk & 1.06 \\
\hline 43 & 2017 & Prasidha Aneka Niaga Tbk & 1.16 \\
\hline 44 & 2018 & Prasidha Aneka Niaga Tbk & 1.02 \\
\hline 45 & 2015 & Nippon Indosari Corpindo Tbk & 2.05 \\
\hline 46 & 2016 & Nippon Indosari Corpindo Tbk & 2.96 \\
\hline 47 & 2018 & Nippon Indosari Corpindo Tbk & 3.57 \\
\hline 48 & 2019 & Nippon Indosari Corpindo Tbk & 1.69 \\
\hline 49 & 2015 & Sekar Laut Tbk & 1.19 \\
\hline 50 & 2017 & Sekar Laut Tbk & 1.26 \\
\hline 51 & 2018 & Sekar Laut Tbk & 1.22 \\
\hline 52 & 2019 & Sekar Laut Tbk & 1.29 \\
\hline 53 & 2015 & Siantar Top Tbk & 1.19 \\
\hline 54 & 2016 & Siantar Top Tbk & 1.65 \\
\hline 55 & 2017 & Siantar Top Tbk & 2.62 \\
\hline 56 & 2018 & Siantar Top Tbk & 1.85 \\
\hline 57 & 2019 & Siantar Top Tbk & 2.85 \\
\hline 58 & 2015 & $\begin{array}{l}\text { Ultra Jaya Milk Industri \& Trading } \\
\text { Com }\end{array}$ & 3.75 \\
\hline 59 & 2017 & $\begin{array}{l}\text { Ultra Jaya Milk Industri \& Trading } \\
\text { Com }\end{array}$ & 4.19 \\
\hline
\end{tabular}

Sumber: Data diolah oleh peneliti, 2020

Berdasarkan tabel 2 diatas, besarnya tingkat likuiditas pada perusahaan manufaktur sektor makanan dan minuman dalam penelitian ini berkisar antara 0,45 yang dimiliki PT Akasha Wira Internasional Tbk pada tahun 2019 sampai 4,19 yang dimiliki PT Ultra Jaya Milk Industri \& Trading Company pada tahun 2017, mean 1,7529 dengan nilai standar deviasi 0,80280 . Nilai rata-rata lebih besar dari standar deviasi yaitu 1,7529> 0,80280. Hal ini menunjukkan bahwa tidak terjadi penyimpangan pada variabel likuiditas karena nilai mean lebih besar dari standar deviasi. Hal ini menggambarkan bahwa nilai likuiditas pada perusahaan manufaktur sektor makanan dan minuman dalam penelitian ini tidak terlalu bervariasi sehingga dapat disimpulkan bahwa nilai mean dapat mempresentasikan keseluruhan nilai likuiditas.

\section{Variabel Leverage (X2) Pada Perusahaan Manufaktur Sektor Makanan dan Minuman Pada Tahun 2015-2019}

Berdasarkan hasil perhitungan tabel 1 pada variabel leverage menggunakan software SPSS versi 24 menganalisi data hasil hitungan Debt To Equity Ratio:

Debt to Equity Ratio $=\quad \frac{\text { Total Liabilities }}{\text { Total Equity }}$

Pada variabel ini memiliki nilai minimum 0,04, nilai maksimum 1,95, mean 0,8873 , dengan nilai standar deviasi 0,44876 dan dengan jumlah pengamatan sebanyak 59 perusahaan. Perusahaan yang memiliki leverage yang tinggi, perusahaan akan mengalami kebangkrutan apabila 
DOI: http://dx.doi.org/10.35137/jabk.v8i2.542

perusahaan tidak segera menyelesaikan permasalahan untuk melunasi kewajiban jangka panjangnya dan perusahaan akan sulit untuk mengalami pinjaman untuk kebutuhan masa yang akan datang (Anggasari and Aji 2018)

Tabel 3 Leverage Pada Perusahaan Manufaktur Makanan dan Minuman Pada Tahun 2015-2019

\begin{tabular}{|c|c|c|c|}
\hline No & Tahun & Nama Perusahaan & $\begin{array}{l}\text { Levera } \\
\text { ge }\end{array}$ \\
\hline 1 & 2015 & Akasha Wira Internasional Tbk & 0.99 \\
\hline 2 & 2016 & Akasha Wira Internasional Tbk & 1 \\
\hline 3 & 2017 & Akasha Wira Internasional Tbk & 0.99 \\
\hline 4 & 2018 & Akasha Wira Internasional Tbk & 0.83 \\
\hline 5 & 2019 & Akasha Wira Internasional Tbk & 0.45 \\
\hline 6 & 2015 & Tiga Pilar Sejahtera Food Tbk & 0.56 \\
\hline 7 & 2016 & Tiga Pilar Sejahtera Food Tbk & 0.54 \\
\hline 8 & 2015 & Budi Starch Sweetener Tbk & 1.95 \\
\hline 9 & 2016 & Budi Starch Sweetener Tbk & 1.52 \\
\hline 10 & 2017 & Budi Starch Sweetener Tbk & 1.46 \\
\hline 11 & 2018 & Budi Starch Sweetener Tbk & 1.77 \\
\hline 12 & 2019 & Budi Starch Sweetener Tbk & 1.33 \\
\hline 13 & 2017 & Bumi Teknokultura Unggul Tbk & 1.67 \\
\hline 14 & 2018 & Bumi Teknokultura Unggul Tbk & 1.28 \\
\hline 15 & 2019 & Bumi Teknokultura Unggul Tbk & 1.32 \\
\hline 16 & 2015 & Cahaya Kalbar Tbk & 1.32 \\
\hline 17 & 2016 & Cahaya Kalbar Tbk & 0.61 \\
\hline 18 & 2017 & Cahaya Kalbar Tbk & 0.54 \\
\hline 19 & 2015 & $\begin{array}{l}\text { Indofood CBP Sukses Makmur } \\
\text { TBK }\end{array}$ & 0.62 \\
\hline 20 & 2016 & $\begin{array}{l}\text { Indofood CBP Sukses Makmur } \\
\text { TBK }\end{array}$ & 0.56 \\
\hline 21 & 2017 & $\begin{array}{l}\text { Indofood CBP Sukses Makmur } \\
\text { TBK }\end{array}$ & 0.56 \\
\hline 22 & 2018 & $\begin{array}{l}\text { Indofood CBP Sukses Makmur } \\
\text { TBK }\end{array}$ & 0.51 \\
\hline 23 & 2019 & $\begin{array}{l}\text { Indofood CBP Sukses Makmur } \\
\text { TBK }\end{array}$ & 0.46 \\
\hline 24 & 2015 & Inti Agri Resources Tbk & 0.04 \\
\hline 25 & 2016 & Inti Agri Resources Tbk & 0.23 \\
\hline 26 & 2017 & Inti Agri Resources Tbk & 0.09 \\
\hline 27 & 2018 & Inti Agri Resources Tbk & 0.09 \\
\hline 28 & 2015 & Indofood Sukses Makmur Tbk & 1.13 \\
\hline
\end{tabular}

110
Printed ISSN : $2406-7415$

Electronic ISSN : 2655 - 9919

Jurnal Akuntansi dan Bisnis Krisnadwipayana Volume 8 No. 2 (Mei - Agustus) 2021

\begin{tabular}{|c|c|c|c|}
\hline 29 & 2017 & Indofood Sukses Makmur Tbk & 0.88 \\
\hline 30 & 2018 & Indofood Sukses Makmur Tbk & 0.93 \\
\hline 31 & 2019 & Indofood Sukses Makmur Tbk & 0.77 \\
\hline 32 & 2016 & Kino Indonesia Tbk & 0.68 \\
\hline 33 & 2017 & Kino Indonesia Tbk & 0.58 \\
\hline 34 & 2018 & Kino Indonesia Tbk & 0.64 \\
\hline 35 & 2019 & Kino Indonesia Tbk & 0.74 \\
\hline No & Tahun & Nama Perusahaan & $\begin{array}{l}\text { Levera } \\
\text { ge }\end{array}$ \\
\hline 36 & 2015 & Mayora Indah Tbk & 1.18 \\
\hline 37 & 2016 & Mayora Indah Tbk & 0.91 \\
\hline 38 & 2017 & Mayora Indah Tbk & 1.03 \\
\hline 39 & 2018 & Mayora Indah Tbk & 1.06 \\
\hline 40 & 2019 & Mayora Indah Tbk & 0.92 \\
\hline 41 & 2015 & Prasidha Aneka Niaga Tbk & 0.91 \\
\hline 42 & 2016 & Prasidha Aneka Niaga Tbk & 1.33 \\
\hline 43 & 2017 & Prasidha Aneka Niaga Tbk & 1.31 \\
\hline 44 & 2018 & Prasidha Aneka Niaga Tbk & 1.87 \\
\hline 45 & 2015 & Nippon Indosari Corpindo Tbk & 1.28 \\
\hline 46 & 2016 & Nippon Indosari Corpindo Tbk & 1.02 \\
\hline 47 & 2018 & Nippon Indosari Corpindo Tbk & 0.51 \\
\hline 48 & 2019 & Nippon Indosari Corpindo Tbk & 0.51 \\
\hline 49 & 2015 & Sekar Laut Tbk & 1.48 \\
\hline 50 & 2017 & Sekar Laut Tbk & 1.07 \\
\hline 51 & 2018 & Sekar Laut Tbk & 1.2 \\
\hline 52 & 2019 & Sekar Laut Tbk & 1.08 \\
\hline 53 & 2015 & Siantar Top Tbk & 0.9 \\
\hline 54 & 2016 & Siantar Top Tbk & 1 \\
\hline 55 & 2017 & Siantar Top Tbk & 0.69 \\
\hline 56 & 2018 & Siantar Top Tbk & 0.6 \\
\hline 57 & 2019 & Siantar Top Tbk & 0.34 \\
\hline 58 & 2015 & $\begin{array}{l}\text { Ultra Jaya Milk Industri dan } \\
\text { Trading Company }\end{array}$ & 0.27 \\
\hline 59 & 2017 & $\begin{array}{l}\text { Ultra Jaya Milk Industri dan } \\
\text { Trading Company }\end{array}$ & 0.23 \\
\hline
\end{tabular}

Sumber: Data diolah oleh peneliti, 2020

Berdasarkan tabel 3 diatas, besarnya tingkat leverage pada perusahaan manufaktur sektor makanan dan minuman dalam penelitian ini berkisar antara 0,04 yang dimiliki PT Inti Agri Resources Tbk 
DOI: http://dx.doi.org/10.35137/jabk.v8i2.542

pada tahun 2015 sampai 1,95 yang dimiliki PT Budi Starch Sweetener Tbk, dan mean 0,8873 , dengan nilai standar deviasi 0,44876 . Nilai rata-rata lebih besar dari standar deviasi yaotu $0,8873>0,44876$. Hal ini menunjukkan bahwa tidak terjadi penyimpangan pada variabel Leverage karena nilai mean lebih besar dari standar deviasi. Hal ini menggambarkan bahwa leverage pada perusahaan manufaktur sektor makanan dan minuman dalam penelitian ini tidak terlalu bervariasi sehingga dapat disimpulkan bahwa nilai mean dapat mempresentasikan keseluruhan nilai leverage.

\section{Variabel Pertumbuhan Perusahaan (X3) Pada Perusahaan Manufaktur Makanan dan Minuman Yang Terdaftar di BEI 2015-2019}

Berdasarkan hasil perhitungan tabel 7 pada variabel likuiditas menggunakan software SPSS versi 24 menganalisi data hasil hitungan Growth:

$$
\text { Growth }=\frac{\mathrm{TA}_{\mathrm{t}}-\mathrm{TA}_{\mathrm{t}-1}}{\mathrm{TA}_{\mathrm{t}-1}} \times 100 \%
$$

Pada variabel ini memiliki nilai minimum $-0,14$, nilai maksimum 0,32 , mean 0,0803 dengan nilai standar deviasi 0,10349 dan dengan jumlah pengamatan sebanyak 59 perusahaan. Pertumbuhan perusahaan dapat mencerminkan peningkatan atau penurunan total asset yang dimiliki oleh perusahaan. Pada pertumbuhan perusahaan dapat dilihat dari presentase perubahan asset pada tahun tetentu terhadap tahun sebelumnya (Saidi 2004).

Tabel 4 Growth Pada Perusahaan Manufaktur Sub Sektor Makanan dan Minuman Pada Periode 2015-2019
Printed ISSN : $2406-7415$

Electronic ISSN : 2655 - 9919

Jurnal Akuntansi dan Bisnis Krisnadwipayana Volume 8 No. 2 (Mei - Agustus) 2021

\begin{tabular}{|c|c|c|c|}
\hline No & Tahun & Nama Perusahaan & Growth \\
\hline 13 & 2017 & $\begin{array}{l}\text { Bumi Teknokultura } \\
\text { Unggul Tbk }\end{array}$ & 0.09 \\
\hline 14 & 2018 & $\begin{array}{l}\text { Bumi Teknokultura } \\
\text { Unggul Tbk }\end{array}$ & -0.03 \\
\hline 15 & 2019 & $\begin{array}{l}\text { Bumi Teknokultura } \\
\text { Unggul Tbk }\end{array}$ & -0.04 \\
\hline 16 & 2015 & Cahaya Kalbar Tbk & 0.16 \\
\hline 17 & 2016 & Cahaya Kalbar Tbk & -0.04 \\
\hline 18 & 2017 & Cahaya Kalbar Tbk & -0.02 \\
\hline 19 & 2015 & $\begin{array}{l}\text { Indofood CBP Sukses } \\
\text { Makmur TBK }\end{array}$ & 0.06 \\
\hline 20 & 2016 & $\begin{array}{l}\text { Indofood CBP Sukses } \\
\text { Makmur TBK }\end{array}$ & 0.09 \\
\hline 21 & 2017 & $\begin{array}{l}\text { Indofood CBP Sukses } \\
\text { Makmur TBK }\end{array}$ & 0.09 \\
\hline 22 & 2018 & $\begin{array}{l}\text { Indofood CBP Sukses } \\
\text { Makmur TBK }\end{array}$ & 0.09 \\
\hline 23 & 2019 & $\begin{array}{l}\text { Indofood CBP Sukses } \\
\text { Makmur TBK }\end{array}$ & 0.13 \\
\hline 24 & 2015 & Inti Agri Resources Tbk & -0.05 \\
\hline 25 & 2016 & Inti Agri Resources Tbk & 0.1 \\
\hline 26 & 2017 & Inti Agri Resources Tbk & -0.14 \\
\hline 27 & 2018 & Inti Agri Resources Tbk & -0.05 \\
\hline 28 & 2015 & $\begin{array}{l}\text { Indofood Sukses } \\
\text { Makmur Tbk }\end{array}$ & 0.04 \\
\hline 29 & 2017 & $\begin{array}{l}\text { Indofood Sukses } \\
\text { Makmur Tbk }\end{array}$ & 0.07 \\
\hline 30 & 2018 & $\begin{array}{l}\text { Indofood Sukses } \\
\text { Makmur Tbk }\end{array}$ & 0.1 \\
\hline 31 & 2019 & $\begin{array}{l}\text { Indofood Sukses } \\
\text { Makmur Tbk }\end{array}$ & 0 \\
\hline
\end{tabular}

\begin{tabular}{|c|c|l|r|}
\hline No & Tahun & Nama Perusahaan & \multicolumn{2}{|c|}{ Growth } \\
\hline 1 & 2015 & $\begin{array}{l}\text { Akasha Wira } \\
\text { Internasional Tbk }\end{array}$ & 0.3 \\
\hline 2 & 2016 & $\begin{array}{l}\text { Akasha Wira } \\
\text { Internasional Tbk }\end{array}$ & 0.17 \\
\hline 3 & 2017 & $\begin{array}{l}\text { Akasha Wira } \\
\text { Internasional Tbk }\end{array}$ & 0.09 \\
\hline 4 & 2018 & $\begin{array}{l}\text { Akasha Wira } \\
\text { Internasional Tbk }\end{array}$ & 0.05 \\
\hline 5 & 2019 & $\begin{array}{l}\text { Akasha Wira } \\
\text { Internasional Tbk }\end{array}$ & -0.07 \\
\hline 6 & 2015 & $\begin{array}{l}\text { Tiga Pilar Sejahtera } \\
\text { Food Tbk }\end{array}$ & 0.23 \\
\hline 7 & 2016 & $\begin{array}{l}\text { Tiga Pilar Sejahtera } \\
\text { Food Tbk }\end{array}$ \\
\hline 8 & 2015 & $\begin{array}{l}\text { Budi Starch Sweetener } \\
\text { Tbk }\end{array}$ & 0.02 \\
\hline 9 & 2016 & $\begin{array}{l}\text { Budi Starch Sweetener } \\
\text { Tbk }\end{array}$ & 0.32 \\
\hline 10 & 2017 & $\begin{array}{l}\text { Budi Starch Sweetener } \\
\text { Tbk }\end{array}$ & -0.1 \\
\hline 11 & 2018 & $\begin{array}{l}\text { Budi Starch Sweetener } \\
\text { Tbk }\end{array}$ & $\begin{array}{l}\text { Budi Starch Sweetener } \\
\text { Tbk }\end{array}$ \\
\hline 12 & 2019 & 0.12 \\
\hline
\end{tabular}


DOI: http://dx.doi.org/10.35137/jabk.v8i2.542

\begin{tabular}{|c|c|c|c|}
\hline 32 & 2016 & Kino Indonesia Tbk & 0.02 \\
\hline 33 & 2017 & Kino Indonesia Tbk & -0.01 \\
\hline 34 & 2018 & Kino Indonesia Tbk & 0.11 \\
\hline 35 & 2019 & Kino Indonesia Tbk & 0.31 \\
\hline 36 & 2015 & Mayora Indah Tbk & 0.1 \\
\hline 37 & 2016 & Mayora Indah Tbk & 0.14 \\
\hline 38 & 2017 & Mayora Indah Tbk & 0.15 \\
\hline 39 & 2018 & Mayora Indah Tbk & 0.18 \\
\hline 40 & 2019 & Mayora Indah Tbk & 0.08 \\
\hline 41 & 2015 & $\begin{array}{l}\text { Prasidha Aneka Niaga } \\
\text { Tbk }\end{array}$ & 0 \\
\hline 42 & 2016 & $\begin{array}{l}\text { Prasidha Aneka Niaga } \\
\text { Tbk }\end{array}$ & 0.05 \\
\hline 43 & 2017 & $\begin{array}{l}\text { Prasidha Aneka Niaga } \\
\text { Tbk }\end{array}$ & 0.06 \\
\hline 44 & 2018 & $\begin{array}{l}\text { Prasidha Aneka Niaga } \\
\text { Tbk }\end{array}$ & 0.01 \\
\hline 45 & 2015 & $\begin{array}{l}\text { Nippon Indosari } \\
\text { Corpindo Tbk }\end{array}$ & 0.26 \\
\hline 46 & 2016 & $\begin{array}{l}\text { Nippon Indosari } \\
\text { Corpindo Tbk }\end{array}$ & 0.08 \\
\hline 47 & 2018 & $\begin{array}{l}\text { Nippon Indosari } \\
\text { Corpindo Tbk }\end{array}$ & -0.04 \\
\hline 48 & 2019 & $\begin{array}{l}\text { Nippon Indosari } \\
\text { Corpindo Tbk }\end{array}$ & 0.07 \\
\hline 49 & 2015 & Sekar Laut Tbk & 0.12 \\
\hline 50 & 2017 & Sekar Laut Tbk & 0.12 \\
\hline 51 & 2018 & Sekar Laut Tbk & 0.17 \\
\hline No & Tahun & Nama Perusahaan & Growth \\
\hline 52 & 2019 & Sekar Laut Tbk & 0.06 \\
\hline 53 & 2015 & Siantar Top Tbk & 0.13 \\
\hline 54 & 2016 & Siantar Top Tbk & 0.22 \\
\hline 55 & 2017 & Siantar Top Tbk & 0 \\
\hline 56 & 2018 & Siantar Top Tbk & 0.12 \\
\hline 57 & 2019 & Siantar Top Tbk & 0.1 \\
\hline 58 & 2015 & $\begin{array}{l}\text { Ultra Jaya Milk Industri } \\
\& \text { Trading Company }\end{array}$ & 0.21 \\
\hline 59 & 2017 & $\begin{array}{l}\text { Ultra Jaya Milk Industri } \\
\text { \& Trading Company }\end{array}$ & 0.22 \\
\hline
\end{tabular}

Sumber: Data diolah oleh peneliti, 2020

Pada variabel pertumbuhan perusahaan memiliki nilai minimum sebesar $-0,14$ yang terdapat di perusahaan Inti Agri Resources Tbk pada tahun 2017, dan memiliki nilai maksimum sebesar 0,32 yang dicapai oleh perusahaan Bumi Teknokultura Unggul Tbk pada tahun
Printed ISSN : $2406-7415$

Electronic ISSN : 2655 - 9919

Jurnal Akuntansi dan Bisnis Krisnadwipayana Volume 8 No. 2 (Mei - Agustus) 2021

2015. Pertumbuhan perusahaan memiliki rata-rata (mean) 0,0803 dan standar deviasi 0,10349. Nilai rata-rata lebih kecil dari standar deviasi yaitu 0,0803 < 0,10349, yang menunjukkan bahwa sebaran nilai pertumbuhan perusahaan tidak baik.

\section{Variabel Profitabilitas (Y) Pada Perusahaan Manufaktur Sektor Makanan dan Minuman Yang Terdaftar di BEI 2015-2019}

Berdasarkan pada tabel 1 variabel profitabilitas memiliki nilai minimum sebesar -0,07 dan nilai maksimum sebesar 0,18. Variabel profitabilitas memiliki rata-rata (mean) sebesar 0,0577 dan standar deviasi 0,06003. Profitabilitas merupakan alat ukur kemampuan perusahaan dalam menghasilkan laba. Apabila perusahaan memiliki laba yang tinggi dari tahun ke tahun, maka perusahaan dapat dikatakan efektif dalam memperoleh laba (Tandelilin 2001).

Tabel 5 Profitabilitas Pada Perusahaan Manufaktur Sub Sektor Makanan dan Minuman Pada Periode 2015-2019

\begin{tabular}{|c|c|l|r|}
\hline No & Tahun & Nama Perusahaan & $\begin{array}{c}\text { Profi } \\
\text { tabili } \\
\text { tas }\end{array}$ \\
\hline 1 & 2015 & Akasha Wira Internasional Tbk & 0.05 \\
\hline 2 & 2016 & Akasha Wira Internasional Tbk & 0.07 \\
\hline 3 & 2017 & Akasha Wira Internasional Tbk & 0.05 \\
\hline 4 & 2018 & Akasha Wira Internasional Tbk & 0.06 \\
\hline 5 & 2019 & Akasha Wira Internasional Tbk & 0.1 \\
\hline 6 & 2015 & Tiga Pilar Sejahtera Food Tbk & 0.04 \\
\hline 7 & 2016 & Tiga Pilar Sejahtera Food Tbk & 0.08 \\
\hline 8 & 2015 & Budi Starch Sweetener Tbk & 0.01 \\
\hline 9 & 2016 & Budi Starch Sweetener Tbk & 0.01 \\
\hline 10 & 2017 & Budi Starch Sweetener Tbk & 0.02 \\
\hline 11 & 2018 & Budi Starch Sweetener Tbk & 0.01 \\
\hline
\end{tabular}


Printed ISSN : $2406-7415$

Electronic ISSN : 2655 - 9919

DOI: http://dx.doi.org/10.35137/jabk.v8i2.542

\begin{tabular}{|c|c|c|c|}
\hline 12 & 2019 & Budi Starch Sweetener Tbk & 0.02 \\
\hline 13 & 2017 & Bumi Teknokultura Unggul Tbk & -0.01 \\
\hline 14 & 2018 & Bumi Teknokultura Unggul Tbk & 0.01 \\
\hline 15 & 2019 & Bumi Teknokultura Unggul Tbk & -0.02 \\
\hline 16 & 2015 & Cahaya Kalbar Tbk & 0.07 \\
\hline 17 & 2016 & Cahaya Kalbar Tbk & 0.18 \\
\hline 18 & 2017 & Cahaya Kalbar Tbk & 0.08 \\
\hline 19 & 2015 & $\begin{array}{l}\text { Indofood CBP Sukses Makmur } \\
\text { TBK }\end{array}$ & 0.11 \\
\hline 20 & 2016 & $\begin{array}{l}\text { Indofood CBP Sukses Makmur } \\
\text { TBK }\end{array}$ & 0.13 \\
\hline 21 & 2017 & $\begin{array}{l}\text { Indofood CBP Sukses Makmur } \\
\text { TBK }\end{array}$ & 0.11 \\
\hline 22 & 2018 & $\begin{array}{l}\text { Indofood CBP Sukses Makmur } \\
\text { TBK }\end{array}$ & 0.14 \\
\hline 23 & 2019 & $\begin{array}{l}\text { Indofood CBP Sukses Makmur } \\
\text { TBK }\end{array}$ & 0.14 \\
\hline 24 & 2015 & Inti Agri Resources Tbk & -0.05 \\
\hline 25 & 2016 & Inti Agri Resources Tbk & -0.07 \\
\hline 26 & 2017 & Inti Agri Resources Tbk & -0.04 \\
\hline 27 & 2018 & Inti Agri Resources Tbk & -0.05 \\
\hline 28 & 2015 & Indofood Sukses Makmur Tbk & 0.09 \\
\hline 29 & 2017 & Indofood Sukses Makmur Tbk & 0.06 \\
\hline 30 & 2018 & Indofood Sukses Makmur Tbk & 0.05 \\
\hline 31 & 2019 & Indofood Sukses Makmur Tbk & 0.06 \\
\hline 32 & 2016 & Kino Indonesia Tbk & 0.06 \\
\hline 33 & 2017 & Kino Indonesia Tbk & 0.03 \\
\hline 34 & 2018 & Kino Indonesia Tbk & 0.04 \\
\hline 35 & 2019 & Kino Indonesia Tbk & 0.11 \\
\hline 36 & 2015 & Mayora Indah Tbk & 0.11 \\
\hline 37 & 2016 & Mayora Indah Tbk & 0.11 \\
\hline 38 & 2017 & Mayora Indah Tbk & 0.11 \\
\hline No & Tahun & Nama Perusahaan & $\begin{array}{c}\text { Profi } \\
\text { tabili } \\
\text { tas }\end{array}$ \\
\hline 39 & 2018 & Mayora Indah Tbk & 0.1 \\
\hline 40 & 2019 & Mayora Indah Tbk & 0.11 \\
\hline 41 & 2015 & Prasidha Aneka Niaga Tbk & -0.07 \\
\hline 42 & 2016 & Prasidha Aneka Niaga Tbk & -0.06 \\
\hline 43 & 2017 & Prasidha Aneka Niaga Tbk & 0.05 \\
\hline 44 & 2018 & Prasidha Aneka Niaga Tbk & -0.07 \\
\hline 45 & 2015 & Nippon Indosari Corpindo Tbk & 0.1 \\
\hline 46 & 2016 & Nippon Indosari Corpindo Tbk & 0.1 \\
\hline 47 & 2018 & Nippon Indosari Corpindo Tbk & 0.03 \\
\hline 48 & 2019 & Nippon Indosari Corpindo Tbk & 0.05 \\
\hline
\end{tabular}

Jurnal Akuntansi dan Bisnis Krisnadwipayana Volume 8 No. 2 (Mei - Agustus) 2021

\begin{tabular}{|c|c|l|r|}
\hline 49 & 2015 & Sekar Laut Tbk & 0.05 \\
\hline 50 & 2017 & Sekar Laut Tbk & 0.04 \\
\hline 51 & 2018 & Sekar Laut Tbk & 0.04 \\
\hline 52 & 2019 & Sekar Laut Tbk & 0.06 \\
\hline 53 & 2015 & Siantar Top Tbk & 0.1 \\
\hline 54 & 2016 & Siantar Top Tbk & 0.07 \\
\hline 55 & 2017 & Siantar Top Tbk & 0.09 \\
\hline 56 & 2018 & Siantar Top Tbk & 0.1 \\
\hline 57 & 2019 & Siantar Top Tbk & 0.17 \\
\hline 59 & 2015 & $\begin{array}{l}\text { Ultra Jaya Milk Industri \& Trading } \\
\text { Company }\end{array}$ & 0.15 \\
\hline 59 & 2017 & $\begin{array}{l}\text { Ultra Jaya Milk Industri \& Trading } \\
\text { Company }\end{array}$ & 0.14 \\
\hline
\end{tabular}

Sumber: Data diolah oleh peneliti, 2020

Berdasarkan tabel 5 diatas, besarnya profitabilitas pada perusahaan manufaktur sektor makanan dan minuman yang menjadi sampel dalam penelitian ini berkisar antara $-0,17$ pada yang dimiliki PT Prasidha Aneka Niaga Tbk pada tahun 2015 sampai 0,18 yang dimiliki oleh PT Cahaya Kalbar Tbk pada tahun 2016, nilai mean sebesar 0,0577 dengan standar deviasi 0,06033. Nilai rata-rata $0,0577<0,06003$ yang menunjukkan bahwa sebaran nilai profitabilitas tidak baik. Pada tabel 1 diatas, dari hasil pengujian statistik deskriptif diketahui bahwa nilai variable rata-rata (mean) Profitabilitas sebesar 0,0577 atau dapat dibulatkan menjadi 0,1000 dan standar deviasi 0,06003. Pada variable likuiditas memiliki nilai rata-rata (mean) sebesar 1,7529 atau sekitar $1,7 \%$ dengan standar deviasi 0,80280 atau setara dengan $1,0 \%$. Pada variabel leverage memiliki nilai rata-rata (mean) 0,8866 atau sekitar 1,0\% dengan standar deviasi 0,45005 atau setara dengan $1,0 \%$. Sedangkan pada Pertumbuhan Perusahaan (Growth) memiliki rata-rata (mean) 0,0803 dengan standar deviasi 0,10349 atau setara dengan $1,0 \%$. 
DOI: http://dx.doi.org/10.35137/jabk.v8i2.542

\section{Uji Asumsi Klasik}

Untuk mengetahui kelayakan model yang dihasilkan dalam suatu hubungan simultan, model dapat diuji dengan menggunakan empat asumsi BLUE (Best Linear Unbiased Estimator). Keempat asumsi tersebut diantara lain; Asumsi Normalitas, Multikoliniearitas, Autokorelasi, dan Heterokedastitas.

\section{Uji Normalitas}

Pengujian normalitas dilakukan dengan tujuan untuk melihat distribusi normal atau tidaknya data yang dianalisis. Pengujian ini untuk melihat apakah dalam model regresi, variabel pengganggu atau residual memiliki distribusi normal. Salah satu cara untuk mengetahui atau mendeteksi nilai residual normal atau tidaknya yaitu dengan menggunakan $U j i$ Kolmogorov Smirnov (Uji K-S).

Data penelitian dilakukan menyebar normal atau memenuhi uji normalitas apabila nilai Asymp.Sig (2-Tailed) variabel residual berada diatas 0,05. Sebaliknya, apabila nilai Asymp.Sig (2-Tailed) variabel residual dibawah 0,05 , maka data tersebut tidak terdistribusi normal atau tidak memenuhi uji normalitas (Ghozali, 2018). Hasil uji normalitas dalam penelitian ini dapat dilihat pada tabel 6 dibawah ini:
Printed ISSN : $2406-7415$

Electronic ISSN : 2655 - 9919

Jurnal Akuntansi dan Bisnis Krisnadwipayana Volume 8 No. 2 (Mei - Agustus) 2021

\begin{tabular}{|l|l|r|}
\hline \multicolumn{2}{|c|}{ One-Sample Kolmogorov-Smirnov Test } \\
\hline \multicolumn{2}{|c|}{} & $\begin{array}{c}\text { Unstandardized } \\
\text { Residual }\end{array}$ \\
\hline $\mathrm{N}$ & Mean & .0000000 \\
\hline Normal & .04351450 \\
Parameters ${ }^{\mathrm{a}, \mathrm{b}}$ & Std. Deviation & .111 \\
\hline Most & Absolute & .110 \\
\cline { 2 - 3 } Extreme & Positive & -.111 \\
\cline { 2 - 3 } Differences & Negative & .111 \\
\hline Test Statistic & $.070^{\mathrm{c}}$ \\
\hline Asymp. Sig. (2-tailed) \\
\hline a. Test distribution is Normal. \\
\hline \multicolumn{2}{|l|}{ b. Calculated from data. } \\
\hline \multicolumn{2}{|l|}{ c. Lilliefors Significance Correction. } \\
\hline
\end{tabular}

Tabel 6 Hasil Uji Normalitas

Sumber: Data diolah oleh peneliti, 2020

Hasil analisis residual dari tabel diatas menyatakan bahwa nilai signifikansi dari fungsi regresi variabel Likuiditas, Leverage, dan Pertumbuhan Perusahaan sebesar 0,070. Nilai tersebut lebih besar dari 0,05 , yaitu $0,070>0,050$ artinya $\mathrm{H}_{0}$ diterima, sehingga menghasilkan model regresi berdistribusi normal.

Selain melakukan uji KolmogorovSmirnov, dalam penelitian ini pengujian asumsi normalitas juga dilakukan dengan menggunakan analisis grafik histogram dan grafik P-P Plot atau normal probability plot. Hasil pengujian disajikan berikut:

Gambar 1: Hasil Uji Grafik Histogram

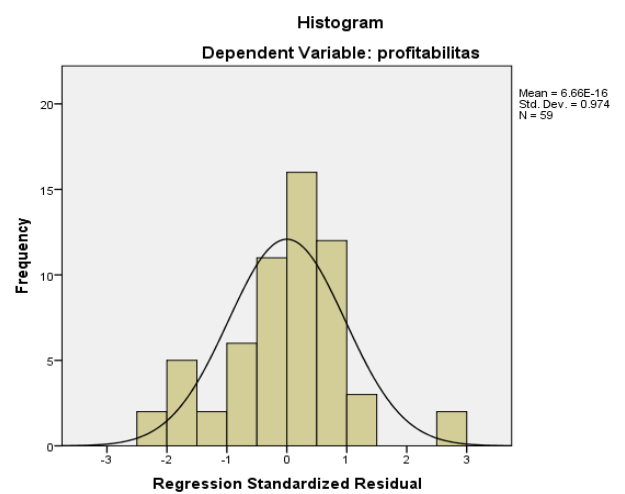

Sumber: Data diolah oleh peneliti, 2020

Berdasarkan gambar 1 terlihat bahwa data terdistribusi secara normal dan berbentuk 
DOI: http://dx.doi.org/10.35137/jabk.v8i2.542

simestris, maka dapat dikatakan bahwa model regresi tidak melenceng (Skewnes) ke kanan atau ke kiri, maka dapat dikatakan bahwa model regresi memenuhi asumsi normalitas.

\section{Uji Multikolinieritas}

Uji multikolinieritas dilakukan untuk memastikan tidak terjadi multikolinieritas dilakukan untuk memastikan tidak terjadi multikolinieritas (saling berkorelasi) antara sesame variabel bebas dalam model (Ghozali 2018). Uji multikolinieritas dapat dilihat dari nilai tolerance dan Variance Inflation Factor (VIF). Regresi bebas dari gangguan multikolinieritas apabila jika:

a. $\mathrm{VIF}<10, \mathrm{H}_{0}$ diterima, artinya tidak ada multikolinieritas.

b. VIF > 10, $\mathrm{H}_{0}$ ditolak, artinya ada multikolinieritas.

Untuk menguji multikolinieritas yaitu nilai VIF yang ditampilkan pada output. Guna mengetahui ada tidaknya multikolinieritas pada model regresi liniear yang diajukan, dapat dilihat dengan uji keragaman varians. Output uji multikolonieritas dapat dilihat pada tabel 7 berikut:

Tabel 7 Hasil Uji Multikolinieritas

\begin{tabular}{|l|l|r|r|}
\hline \multicolumn{3}{|c|}{ Coefficients $^{\mathbf{a}}$} \\
\hline \multirow{2}{*}{ Model } & \multicolumn{2}{c|}{ Collinearity Statistics } \\
\cline { 2 - 4 } & Tolerance & \multicolumn{1}{c|}{ VIF } \\
\hline \multirow{2}{*}{1} & likuiditas & .825 & 1.212 \\
\cline { 2 - 4 } & leverage & .834 & 1.198 \\
\cline { 2 - 4 } & pertumbuhan perusahaan & .893 & 1.120 \\
\hline \multicolumn{2}{|c|}{1.4 Dependent Variable: profitabilitas } \\
\hline \multicolumn{2}{|l|}{} \\
\hline
\end{tabular}

Sumber: Data diolah oleh peneliti, 2020

Berdasarkan dari hasil statistic uji multikolinieritas pada tabel 7 diatas menunjukkan bahwa nilai tolerance dan VIF untuk variabel likuiditas adalah 0,825 dan 1,212; nilai tolerance dan VIF untuk
Printed ISSN : $2406-7415$

Electronic ISSN : 2655 - 9919

Jurnal Akuntansi dan Bisnis Krisnadwipayana

Volume 8 No. 2 (Mei - Agustus) 2021

variabel leverage adalah 0,834 dan 1,198; dan nilai tolerance dan VIF untuk variabel pertumbuhan perusahaan 0,893 dan 1,120. Sehingga seluruh variable independen pada persamaan regresi mempunyai toleransi $>0,1$ dan variance inflation factor $(\mathrm{VIF})<10$.

Hasil dari perhitungan statistik bahwa semua variabel menghasilkan nilai variance inflation factor (VIF) $<10$. Dimana nilai VIF dari ketiga variabel bebas tersebut, $\mathrm{H}_{0}$ diterima, artinya tidak ada gejala multikolinieritas.

\section{Uji Autokorelasi}

Auto korelasi adalah korelasi (hubungan) yang terjadi antara anggotaanggota dari serangkaian pengamatan yang tersusun dalam rangkaian waktu (time series). Hal ini menunjukkan hubungan antara nilai-nilai yang beruntun dari variabel-variabel yang sama. Untuk mendeteksi autokorelasi pada program SPSS dapat dilakukan dengan membandingkan hasil Durbin Watson $(D-W)$ hitung dengan yang ditampilkan pada tabel model summary dengan ketentuan umum D-W kategori ukuran sebagai berikut:

a) Jika DW dibawah -2 , berarti ada autokorelasi positif

b) Jika DW diantara -2 sampai +2 tidak ada autokorelasi

c) Jika DW diatas +2 , berarti ada autokorelasi negatif

Tabel 8 Hasil Uji Autokorelasi

\begin{tabular}{|l|c|r|r|r|r|}
\hline \multicolumn{7}{|c|}{ Model Summary $^{\mathbf{b}}$} \\
\hline Model & $\mathrm{R}$ & $\begin{array}{c}\mathrm{R} \\
\text { Square }\end{array}$ & $\begin{array}{c}\text { Adjusted } \\
\text { R Square }\end{array}$ & $\begin{array}{c}\text { Std. Error } \\
\text { of the } \\
\text { Estimate }\end{array}$ & $\begin{array}{c}\text { Durbin- } \\
\text { Watson }\end{array}$ \\
\hline 1 & $.689^{\mathrm{a}}$ & .474 & .445 & .04470 & 2.086 \\
\hline
\end{tabular}


DOI: http://dx.doi.org/10.35137/jabk.v8i2.542

Sumber: Data diolah oleh peneliti, 2020

Dilakukan uji autokorelasi karena data yang digunakan dalam penelitian ini adalah data timeseries (berkala). Untuk melihat uji autokorelasi adalah dengan membandingkan nilai Durbin Watson (DW). Berdasarkan hasil pengujian Durbin Watson sebesar 2,086. Nilai tersebut kemudian dibandingkan dengan nilai dU dan 4-dU diambil dari tabel Durbin Watson dengan $\mathrm{n}=59$ dan $\mathrm{k}=3$, sehingga diperoleh dU sebesar 1,6875. Dengan syarat mengambil keputusan yang menjadi ketentuan nilai $\mathrm{DW}>\mathrm{dU}(2,086>1,6875)$ dan $\mathrm{DW}<4-\mathrm{dU}(2,086<2,3125)$.

Dengan demikian dapat disimpulkan bahwa tidak terjadi autokorelasi antara variabel independen sehingga penelitian layak untuk dilanjutkan.

\section{Uji Heterokedastitas}

Uji heterokedastitas dimaksudkan untuk mengetahui apakah dalam dalam model regresi terjadi ketidaksamaan variabel dari residual atau pengamatan ke pengamatan yang lain. Jika varian dari residual atau pengamatan ke pengamatan lain berbeda maka disebut heterokedastitas. Model yang baik harus terbebas dari heterokestitas atau dengan kata lain harus homokedastitas yaitu varian dari residual satu pengamatan ke pengamatan lain adalah tetap, oleh karena itu pengujian ini hanya diperuntukkan bagi hubungan simultan.

Untuk menentukan ada atau tidaknya heterokedastistas dalam penelitian ini dilakukan dengan cara melihat grafik scatter plot antara nilai prediksi variabel dependen (ZEPRED) dengan residualnya (SRESID). Dasar analisisnya:

1. Jika ada pola tertentu, seperti titik-titik yang ada membentuk pola tertentu
Printed ISSN : $2406-7415$

Electronic ISSN : 2655 - 9919

Jurnal Akuntansi dan Bisnis Krisnadwipayana

Volume 8 No. 2 (Mei - Agustus) 2021

yang teratur (bergelombang, melebar, kemudian menyempit), maka mengindikasikan oleh terjadi heterokedastistas.

2. Jika tidak ada pola yang jelas serta titik-titik menyebar di atas dan di bawah angka nol pada sumbu Y, maka tidak terjadi heterokedastistas.

Gambar 2 Hasil Uji Heterokedastitas

Sumber: Data diolah oleh Peneliti, 2020

Berdasarkan gambar 2 diatas, dinyatakan bahwa titik-titik menyebar secara acak serta tersebar baik diatas maupun dibawah angka 0 pada sumbu Y. Dengan demikian dinyatakan bahwa model regresi ini tidak terjadi gejala heteroskedastitas.

\section{Uji Model}

\section{Analisis Regresi Linier Berganda}

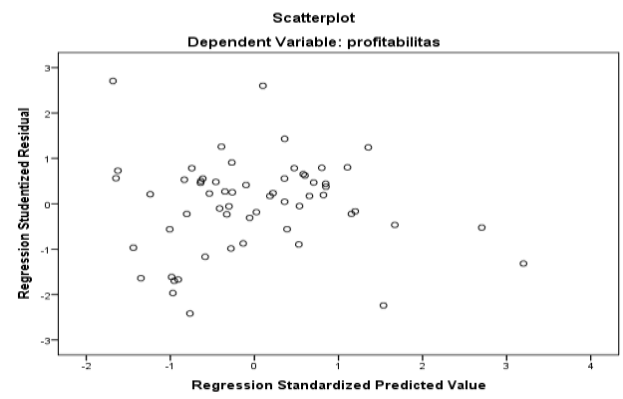

Metode analisis data yang digunakan adalah metode regresi linier berganda. Secara umum analisis regresi linier berganda menurut (Ghozali 2018) adalah analisis yang dilakukan untuk mengetahui ada atau tidaknya pengaruh suatu hubungan antara dua variabel yaitu variable independen dengan variable dependen. Analisis regresi linier dalam penelitian ini adalah untuk mengetahui apakah terdapat pengaruh antara Likuiditas, Leverage, dan Pertumbuhan Perusahaan terhadap Profitabilitas. Model 
DOI: http://dx.doi.org/10.35137/jabk.v8i2.542

regresi linier berganda yang digunakan adalah sebagai berikut:

Rumus:

$Y=\alpha+\beta 1 X 1+\beta 2 X 2+\beta 3 X 3+\varepsilon$

Keterangan:

$\begin{array}{lll}\mathrm{Y} & : & \text { Profitabilitas } \\ \alpha & : & \text { Konstanta } \\ \beta 1, \beta 2, \beta 3 & : & \text { Koefisien regresi } \\ \mathrm{X}_{1} & : & \text { Likuiditas } \\ \mathrm{X}_{2}: & : & \text { Leverage } \\ \mathrm{X}_{3} & : & \text { Pertumbuhan } \\ \text { Perusahaan } & & \\ \varepsilon & : & \text { Pengaruh faktor lain }\end{array}$

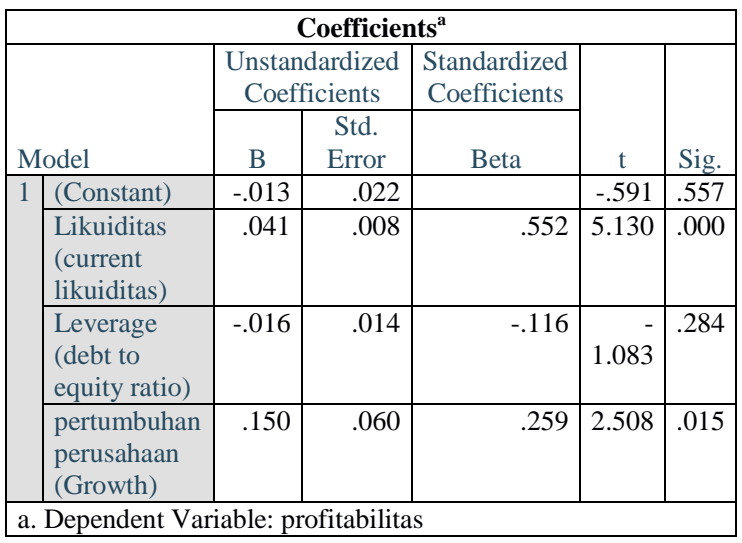

Tabel 9 Hasil Uji Analisis Regresi Linier Berganda

Sumber: Data diolah oleh peneliti, 2020

Setelah dilakukan dengan menggunakan software SPSS Versi 24.0 terhadap data-data yang ditentukan, maka hasih penelitian tentang pengaruh variabelvariabel bebas: Likuiditas, Leverage, dan Pertumbuhan Perusahaan terhadap Profitabilitas seperti tabel adalah hasil uji regresi berganda sehinggu diperoleh persamaan:
Printed ISSN : $2406-7415$

Electronic ISSN : 2655 - 9919

Jurnal Akuntansi dan Bisnis Krisnadwipayana

Volume 8 No. 2 (Mei - Agustus) 2021

$\mathrm{Y}=-\mathbf{0 , 0 1 3}+(\mathbf{0 , 0 4 1} \mathrm{X} 1)+(-0,016) \mathrm{X} 2+(0,150) \mathrm{X} 3+\varepsilon$

Interprestasi dari persamaan tersebut adalah sebagai berikut:

$\mathbf{a}=$ Dari persamaan regresi berganda diatas, diketahui mempunyai konstanta sebesar -0,013. Hal ini menunjukkan bahwa jika variabel-variabel independen diasumsikan dalam keadaam tetap, maka variabel dependen akan turun sebesar $-1,3 \%$

$\boldsymbol{\beta 1}=0,041$, menunjukkan jika variabel likuditas $\left(\mathrm{X}_{1}\right)$ berpengaruh secara positif signifikan, artinya apabila likuiditas meningkat 4,1\% maka Return on Assets (Y) akan naik sebesar 0,041 atau 4.1\% dengan asumsi variabel lain konstan.

$\boldsymbol{\beta 2}=-0,016$, menunjukkan jika variabel leverage $\left(\mathrm{X}_{2}\right)$ berpengaruh secara negatif, artinya apabila leverage mengalami peningkatan sebesar 100 persen, sedangkan variabel lainnya tidak mengalami perubahan (konstan), maka profitabilitas akan menurun sebesar $-1,6 \%$.

$\boldsymbol{\beta 3}=0,150$, menunjukkan bahwa variabel pertumbuhan perusahaan $\left(\mathrm{X}_{3}\right)$ berpengaruh secara positif, artinya apabila pertumbuhan perusahaan mengalami peningkatan sebesar satu kali, sedangkan variabel lainnya tidak mengalami perubahan (konstan), maka profitabilitas akan meningkat sebesar $15 \%$.

\section{Koefisien Determinasi $\left(\mathbf{R}^{2}\right)$}

Koefisien determinasi bertujuan untuk mengetahui derajat pengaruh dalam bentuk persentase dari variabel bebas (variabel independen) yaitu likuiditas, leverage, dan pertumbuhan perusahaan terhadap variabel terikat (variabel dependen) yaitu Profitabilitas (Return on Assets). Hasil perhitungan 
DOI: http://dx.doi.org/10.35137/jabk.v8i2.542

koefisien determinasi $\left(\mathrm{R}^{2}\right)$ yang telah diolah dengan program SPSS versi 24 sebagai berikut:

Tabel 10 Hasil Uji Koefisien Determinasi

\begin{tabular}{|l|c|r|c|c|}
\hline \multicolumn{5}{|c|}{ Model Summary $^{\text {b }}$} \\
\hline $\begin{array}{l}\text { Mode } \\
1\end{array}$ & $\mathrm{R}$ & R Square & $\begin{array}{c}\text { Adjusted R } \\
\text { Square }\end{array}$ & $\begin{array}{c}\text { Std. Error of } \\
\text { the Estimate }\end{array}$ \\
\hline 1 & $.689^{\mathrm{a}}$ & .474 & .445 & .04470 \\
\hline \multicolumn{5}{|c|}{ a. Predictors: (Constant), growth, leverage, likuiditas } \\
\hline \multicolumn{4}{|l}{ b. Dependent Variable: profitabilitas } \\
\hline
\end{tabular}

Sumber: Data diolah oleh peneliti, 2020

Hasil perhitungan SPSS versi 24 uji $\mathrm{R}^{2}$ diatas menunjukkan bahwa nilai $R$ Square 0,474, hal ini dapat diartikan bahwa kinerja keuangan perusahaan atau Profitabilitas (Return on Assets) 47,4\% ditentukan oleh variabel independen dalam penelitian ini atau dipengaruhi oleh Likuiditas (Current Ratio), Leverage (Debt to Equity Ratio), dan Pertumbuhan Perusahaan (Growth). Sedangkan sisanya sebesar 52,6\% (100$47,4 \%$ ) dipengaruhi oleh variabel lain.

\section{Hipotesis}

\section{Uji Signifikansi Parsial (Uji Statistik t)}

Uji $\mathrm{t}$ ini digunakan untuk mengetahui signifikansi pengaruh masing-masing variabel bebas atau independen Likuditas (Current Ratio), Leverage (Debt to Equity Ratio), dan Pertumbuhan Perusahaan (Growth) terhadap variabel terikat atau dependen Profitabilitas (Return on Assets) secara parsial.

Dengan kriteria pengujian:

a. $\mathrm{H}_{0}$ diterima $\mathrm{Ha}$ ditolak yaitu apabila profitabilitas $>0,05$

b. $\mathrm{H}_{0}$ ditolak $\mathrm{Ha}$ diterima yaitu apabila profitabilitas $<0,05$
Printed ISSN : $2406-7415$

Electronic ISSN : 2655 - 9919

Jurnal Akuntansi dan Bisnis Krisnadwipayana Volume 8 No. 2 (Mei - Agustus) 2021

Hasil perhitungan dengan program SPSS adalah sebagai berikut:

Tabel 11 Hasil Pengujian Parsial (Uji t)

\begin{tabular}{|c|c|c|c|c|c|c|}
\hline \multicolumn{7}{|c|}{ Coefficients $^{\mathrm{a}}$} \\
\hline & & \multicolumn{2}{|c|}{$\begin{array}{c}\text { Unstandardized } \\
\text { Coefficients }\end{array}$} & \multirow{2}{*}{$\begin{array}{c}\text { Standardized } \\
\text { Coefficients } \\
\text { Beta }\end{array}$} & \multirow[b]{2}{*}{ t } & \multirow[b]{2}{*}{ Sig. } \\
\hline & & B & $\begin{array}{l}\text { Std. } \\
\text { Error }\end{array}$ & & & \\
\hline \multirow[t]{4}{*}{1} & (Constant) & -.013 & .022 & & -.612 & .543 \\
\hline & $\begin{array}{l}\text { Likuiditas } \\
\text { (Current } \\
\text { Ratio) }\end{array}$ & .041 & .008 & .553 & 5.142 & .000 \\
\hline & $\begin{array}{l}\text { Leverage } \\
\text { (Debt to } \\
\text { Equity } \\
\text { Ratio) }\end{array}$ & -.015 & .014 & -.114 & 1.063 & .292 \\
\hline & $\begin{array}{l}\text { Pertumbuhan } \\
\text { Perusahaan } \\
\text { (Growth) }\end{array}$ & .150 & .060 & .259 & 2.503 & .015 \\
\hline
\end{tabular}

Sumber: Data diolah oleh peneliti, 2020

Dari hasil uji t diatas dapat disimpulkan bahwa:

\section{1. $\mathrm{H}_{1}$ : Likuiditas berpengaruh terhadap Profitabilitas}

Hasil perhitungan statistic secara parsial pada tabel 11 diatas variabel independen Likuiditas (Current Ratio) berpengaruh positif memiliki nilai signifikansi sebesar 0,000 atau signifikansi lebih kecil daripada $a=0,05(0,000<$ 0,05), dan nilai statistik t-hitung lebih besar dari t-tabel $5,142>1,67303(n-k=59-4=55$, dilihat dari t-tabel), maka artinya Likuiditas memiliki pengaruh positif dan signifikan terhadap Profitabilitas. Hasil penelitian ini menyatakan bahwa $\mathrm{H}_{1}$ diterima.

\section{2. $\mathrm{H}_{2}$ : Leverage berpengaruh terhadap Profitabilitas}

Hasil perhitungan statistik secara parsial pada tabel 15 diatas menunjukkan variabel Leverage (Debt to Equity Ratio) memiliki nilai signifikansi sebesar 0,292, atau signinfikansi lebih besar daripada $\mathrm{a}=$ $0,05(0,292>0,05)$, dan nilai statistik $\mathrm{t}$ hitung lebih kecil daripada t-tabel $-1,063<1,67303(n-k=59-4=55$, 
DOI: http://dx.doi.org/10.35137/jabk.v8i2.542

dilihat dari t-tabel), maka dapat diartikan bahwa Leverage tidak berpengaruh terhadap Profitabilitas. Hasil penelitian ini menyatakan bahwa $\mathrm{H}_{2}$ ditolak

\section{3. $\mathrm{H}_{3}$ : Pertumbuhan Perusahaan berpengaruh terhadap Profitabilitas}

Hasil perhitungan statistic secara parsial pada tabel 15 diatas menunjukkan variabel Pertumbuhan Perusahaan (Growth) memiliki nilai signifikansi sebesar 0,015 atau signifikansi lebih kecil daripada $a=0,05(0,015>0,05)$, dan nilai statistik t hitung lebih besar daripada ttabel yaitu 2,503 >1,67303 $(\mathrm{df}=59-4=$ 55, dilihat dari tabel t) yang dapat diartikan bahwa Pertumbuhan Perusahaan memiliki pengaruh positif signifikan terhadap Profitabilitas. Hasil dari penelitian ini menyatakan bahwa $\mathrm{H}_{3}$ diterima.

\section{Uji Signifikansi Simultan (Uji F)}

Uji $f$ digunakan untuk melihat pengaruh Likuiditas, Leverage, dan Pertumbuhan Perusahaan secara simultan dengan Profitabilitas (Return on Assets), dapat dilakukan dengan menggunakan uji statistik F. Uji F ini adalah untuk melihat apakah variabel independen berpengaruh terhadap variabel dependen secara simultan. Dengan tingkat signifikansi 5\% maka hasil yang diperoleh dari uji simultan (F) atas data-data tersebut sebagai berikut:

Tabel 12 Hasil Pengujian Simultan (Uji F) Sumber: Data diolah oleh peneliti, 2020

Dari uji anova atau F-test, diperoleh nilai $\mathrm{F}$ hitung sebesar 16,532 dan $\mathrm{F}$ tabel sebesar $2,77\left(\mathrm{df}_{1}=4-1, \mathrm{df}_{2}=59-4\right)$ yang dapat disimpulkan 16,532> 2,77 dengan
Printed ISSN : $2406-7415$

Electronic ISSN : 2655 - 9919

Jurnal Akuntansi dan Bisnis Krisnadwipayana Volume 8 No. 2 (Mei - Agustus) 2021

tingkat signifikansi sebesar 0,000. Berdasarkan hasil tersebut dapat disimpulkan bahwa variabel Likuiditas, Leverage, dan Pertumbuhan Perusahaan secara simultan berpengaruh signifikan terhadap variabel Profitabilitas (Return on Assets). Hasil penelitian ini menyatakan $\mathrm{H}_{4}$ diterima.

\section{PEMBAHASAN HASIL PENELITIAN}

Secara Parsial Hasil Pengaruh Likuiditas, Leverage, dan Pertumbuhan Perusahaan Terhadap Profitabilitas.

Dari hasil pengujian diatas pengaruh likuiditas, leverage dan pertumbuhan perusahaan terhadap profitabilitas diperoleh persamaan sebagai berikut:

$\mathrm{Y}=-\mathbf{0 , 0 1 3}+(\mathbf{0 , 0 4 1} \mathrm{X} 1)+(-0,016) \mathrm{X} 2+(0,150) \mathrm{X} 3+\varepsilon$

1. Current Ratio dengan proksi Likuiditas berpengaruh secara positif tProfitabilitas pada perusahaan manfuaktur sektor makanan dan minuman pada tahun 2015-2019, memperoleh hasil analisis data hipotesis pertama $\left(\mathrm{H}_{1}\right)$. Diketahui bahwa nilai t hitung 5,142 dan nilai signifikansi $0,000<0,05$. Sehingga dapat disimpulkan bahwa Likuiditas berpengaruh positif dan signifikan terhadap Profitabilitas. Dan hipotesis pertama $\left(\mathrm{H}_{1}\right)$ diterima.

2. Debt to Equity Ratio dengan proksi Leverage berpengaruh secara negatif

\begin{tabular}{|c|c|c|c|c|c|c|}
\hline \multicolumn{7}{|c|}{ ANOVA $^{a}$} \\
\hline \multicolumn{2}{|c|}{ Model } & $\begin{array}{c}\text { Sum of } \\
\text { Squares }\end{array}$ & df & $\begin{array}{l}\text { Mean } \\
\text { Square }\end{array}$ & $\mathrm{F}$ & Sig. \\
\hline \multirow[t]{3}{*}{1} & Regression & .099 & 3 & .033 & 16.532 & $.000^{\mathrm{b}}$ \\
\hline & Residual & .110 & 55 & .002 & & \\
\hline & Total & .209 & 58 & & & \\
\hline \multicolumn{7}{|c|}{ a. Dependent Variable: profitabilitas } \\
\hline
\end{tabular}


DOI: http://dx.doi.org/10.35137/jabk.v8i2.542

terhadap Profitabilitas pada perusahaan manufaktur sektor makanan dan minuman yang terdaftar di Bursa Efek Indonesia tahun 2015-2019, memperoleh hasil analisis data hipotesis kedua $\left(\mathrm{H}_{2}\right)$ diketahui bahwa nilai t hitung $-1,063$ dan dengan nilai signifikansi $0,292>0,05$. Sehingga dapat disimpulkan bahwa Leverage tidak berpengaruh terhadap Profitabilitas. Dan hipotesis kedua $\left(\mathrm{H}_{2}\right)$ ditolak.

3. Growth dengan proksi Pertumbuhan Perusahaan berpengaruh secara positif terhadap Profitabilitas pada perusahaan manufaktur sektor makanan dan minuman yang terdaftar di Bursa Efek Indonesia tahun 2015-2019, memperoleh hasil analisis data hipotesis ketiga $\left(\mathrm{H}_{3}\right)$ diketahui bahwa nilai t-hitung 2,503 dan dengan nilai signifikansi $0,015<0,05$. Sehingga dapat disimpulkan bahwa Pertumbuhan Perusahaan berpengaruh signifikan terhadap Profitabilitas. Dan hipotesis ketiga $\left(\mathrm{H}_{3}\right)$ diterima.

\section{Secara Simultan Hasil Pengaruh Likuiditas, Leverage, dan Pertumbuhan Perusahaan Terhadap Profitabilitas}

Penelitian ini bertujuan untuk mengetahui pengaruh likuiditas, leverage, dan pertumbuhan perusahaan berpengaruh secara simultan terhadap profitabilitas.

Berdasarkan hasil analisis data diatas diketahui bahwa F-hitung sebesar 16,532 dan signifikansi sebesar $0,000<0,05$. Maka hipotesis keempat $\left(\mathrm{H}_{4}\right)$ diterima, artinya Likuiditas, Leverage, dan Pertumbuhan Perusahaan secara simultan berpengaruh terhadap Profitabilitas pada Perusahaan Manufaktur Sektor Makanan dan Minuman yang terdaftar di Bursa Efek Indonesia (BEI) Periode tahun 2015-2019.
Printed ISSN : $2406-7415$

Electronic ISSN : 2655 - 9919

Jurnal Akuntansi dan Bisnis Krisnadwipayana

Volume 8 No. 2 (Mei - Agustus) 2021

Nilai Adjusted $\mathrm{R}^{2}$ sebesar 0,474. Hal ini menunjukkan bahwa Likuiditas, Leverage dan Pertumbuhan Perusahaan dipengaruhi oleh Profitabilitas. Likuiditas, Leverage, dan Pertumbuhan perusahaan sebesar $47,4 \%$, sedangkan sisanya $52,5 \%$ dipengaruhi oleh variabel lain diluar penelitian ini.

\section{KESIMPULAN DAN SARAN}

\section{Kesimpulan}

Penelitian ini mencoba untuk meneliti bagaimana pengaruh likuiditas, leverage, dan pertumbuhan perusahaan terhadap profitabilitas. Berdasarkan hasil analisis regresi berganda menunjukkan sebagian besar hipotesis diterima, yaitu hipotesis pertama, dan hipotesis ketiga, sedangkan pada hipotesis kedua gagal diterima. Adapun hasil penelitian ini adalah sebagai berikut:

1. Berdasarkan hipotesis pertama, rasio likuiditas (current ratio) memiliki pengaruh terhadap Profitabilitas (return on assets). Hasil ini sejalan dengan penelitian yang dilakukan oleh (Lely, 2019) dan (Silvia and Sari, 2018). Hal ini terjadi karena Current Ratio pada Likuiditas dapat mencerminkan perusahaan dapat memenuhi kewajiban jangka pendeknya.

Hal ini membuktikan bahwa perusahaan menjalankan operasional penempatan dananya yang besar terhadap aset lancar. Dengan tingkat likuiditas akan lebih banyak pendanaan yang berasal dari hutang perusahaan tersebut.

Jika perusahaan semakin tinggi yang ditunjukkan pada likuiditas, maka hal ini membuktikan bahwa semakin 
DOI: http://dx.doi.org/10.35137/jabk.v8i2.542

tinggi juga asset yang dimiliki oleh perusahaan. Namun, apabila perusahaan tidak menggunakan assetnya untuk berinvestasi maka nilai Profitabilitas pada perusahaan akan mengalami penurunan. Likuiditas berpengaruh positif dan signifikan terhadap profitabilitas. Hal tersebut dibuktikan dengan besarnya koefisien beta (B) 0,041. T-hitung sebesar 5,142 yang lebih besar dari t-tabel pada tingkat signifikansi 5\% yaitu sebesar 1,67303 $(\mathrm{n}-\mathrm{k}=59-4=55)$, dan nilai signifikan sebesar $0,000<0,050$, maka hasil menunjukkan bahwa hipotesis pertama $\left(\mathrm{H}_{1)}\right.$ diterima. Semakin tinggi likuiditas maka semakin besar juga profitabilitas.

2. Berdasarkan hipotesis kedua, rasio leverage (debt to equity ratio) tidak berpengaruh terhadap profitabilitas (return on assets). Penelitian ini sejalan dengan penelitian yang dilakukan oleh (Hilmi and Hidayati, 2017) dan (Anggasari and Oji, 2018). Rasio leverage memiliki konsekuensi apabila penggunaan hutang tidak diperhatikan dengan baik, akan menimbulkan beban bunga yang sifatnya tetap. Semakin besar biaya yang harus ditanggung perusahaan untuk ditanggung perusahaan maka akan menurunkan profitabilitas yang dimiliki perusahaan. Pada penelitian Leverage tidak berpengaruh terhadap Profitabilitas. Hal tersebut dibuktikannya koefisien beta (B) sebesar -0,015. T-hitung sebesar $-1,063$ yang lebih kecil dari ttabel 1,67303 ( $\mathrm{n}-\mathrm{k}=59-4=55)$, dan nilai signifikan 0,292 yang dimana lebih besar dibanding 0,05 , maka hasil menunjukkan bahwa hipotesis $\left(\mathrm{H}_{2}\right)$ ditolak. Semakin tinggi leverage, semakin rendah profitabilitas.
Printed ISSN : $2406-7415$

Electronic ISSN : 2655 - 9919

Jurnal Akuntansi dan Bisnis Krisnadwipayana

Volume 8 No. 2 (Mei - Agustus) 2021

3. Berdasarkan hipotesis ketiga, pertumbuhan perusahaan (growth) berpengaruh terhadap profitabilitas (return on assets). Hasil penelitian ini sejalan dengan penelitian yang dilakukan oleh (Pashah et al. 2018). Pertumbuhan perusahaan merupakan tolak ukur apakah perusahaan memiliki prospek pertumbuhan yang baik pada masa yang akan datang. Pada hasil penelitian ini, pertumbuhan perusahaan memiliki pengaruh positif yang signifikan terhadap proftabilitas. Hal ini dibuktikan dengan koefisien beta (B) 0,150. T-hitung sebesar 2,503 yang lebih besar dari t-tabel 1,67303 $(n-k, 59-4=55)$ dan nilai signifikansi 0,015 yang dimana lebih kecil dibanding 0,05 , maka hasil menunjukkan bahwa hipotesis ketiga $\left(\mathrm{H}_{3}\right)$ diterima. Pada pertumbuhan perusahaan yang memiliki tingkat yang tinggi dapat mempengaruhi profitabilitas menunjukkan perusahaan telah mampu melakukan efisiensi dalam menggunakan dana.

4. Berdasarkan hipotesis keempat, likuiditas (current ratio), leverage (debt to equity ratio), dan pertumbuhan perusahaan (growth) berpengaruh terhadap profitabilitas. Hasil penelitian ini sejalan dengan penelitian yang dilakukan oleh (Lely, 2019). Hasil pengujian secara simultan ini berpengaruh signifikan terhadap variabel terikat yaitu profitabilitas. Hal ini didukung dengan besarnya f-hitung sebesar 16,532 lebih besar dari f-tabel yaitu $2,77\left(\mathrm{df}_{1}=4-1, \mathrm{df}_{2}=59-4\right)$ dan nilai signifikansi sebesar $0,000<0,05$. Maka pada hipotesis keempat $\left(\mathrm{H}_{4}\right)$ diterima, sehingga kesimpulannya likuiditas, leverage, dan pertumbuhan perusahaan secara simultan 
DOI: http://dx.doi.org/10.35137/jabk.v8i2.542

berpengaruh signifikan terhadap profitabilitas.

5. Pada penelitian ini memperoleh nilai Adjusted $\mathrm{R}^{2}$ sebesar 0,474. Hal ini menunjukkan bahwa Likuiditas, Leverage dan Pertumbuhan Perusahaan dipengaruhi oleh Profitabilitas. Likuiditas, Leverage, dan Pertumbuhan perusahaan sebesar $47,4 \%$, sedangkan sisanya $52,5 \%$ dipengaruhi oleh variabel lain diluar penelitian ini.

\section{SARAN}

Berdasarkan hasil penelitian yang telah dilakukan dapat disampaikan beberapa rekomendasi yang bisa menjadi masukkan, antara lain:

1. Penelitian mengenai Profitabilitas memberikan bukti adanya pengaruh dari Likuiditas, Leverage, dan Pertumbuhan Perusahaan manufaktur sektor makanan dan minuman yang terdaftar di Bursa Efek Indonesia tahun 2015-2019. Untuk itu kepada pembaca dapat mengembangkan penelitian ini dan menambah objek dari berbagai sektor agar dapat memberikan referensi kepada inversor, calon investor, dan pengguna lain untuk pengambilan keputusan investasi yang baik.

2. Penelitian mengenai Profitabilitas memberikan adanya bukti pengaruh dari variabel Likuiditas, Leverage, dan Pertumbuhan perusahaan pada perusahaan manufaktur sektor makanan dan minuman yang terdaftar di Bursa Efek Indonesia tahun 2015-2019. Untuk itu kepada perusahaan penelitian ini dapat menjadi bahan pertimbangan perusahaan untuk lebih
Printed ISSN : $2406-7415$

Electronic ISSN : 2655 - 9919

Jurnal Akuntansi dan Bisnis Krisnadwipayana

Volume 8 No. 2 (Mei - Agustus) 2021

memaksimalkan

dan

mempertahankan Profitabilitas

ditahun selanjutnya agar perusahaan memiliki profit yang berkualitas.

3. Diharapkan bagi para pembaca, sehubungan dengan keterbatasan jumlah variabel independen dalam penelitian ini, untuk itu kepada peneliti dalam melakukan penelitian selanjutnya mengenai profitabilitas, lebih menambah variabel independen lain yang dapat mempengaruhi profitabilitas agar dapat menjadi bahan pertimbangan bagi perusahaan dalam mengambil keputusan.

\section{DAFTAR PUSTAKA}

Adibah, M. (2013). Pengaruh Pertumbuhan Perusahaan, Stabilitas Penjualan, Profitabilitas, \& Ukuran Perusahaan Terhadap Struktur Modal Perusahaan Consumer Goods Yang Terdaftar di Bursa Efek Indonesia 20092011. Available at: https://eprints.uny.ac.id/17833/

Afrinda, Nidya. (2013). Analisis Pengaruh Likuiditas Dan Solvabilitas Terhadap Profitabilitas Pada Perusahaan Makanan \& Minuman Yang Terdaftar Di BEI. Jurnal Fakultas Ekonomi, pp. 1-23. Available at: https://docplayer.info/99529339Analisis-pengaruh-likuiditas-dansolvabilitas-terhadap-profitabilitaspada-perusahaan-makanan-danminuman-yang-terdaftar-di-bursaefek-indonesia-bei.html

Agustin, A. L., Darminto and Handayani, S. R. (2013). Analisis rasio untuk menilai kinerja keuangan 
DOI: http://dx.doi.org/10.35137/jabk.v8i2.542

perusahaan. Jurnal Administrasi Bisnis (JAB), 2(1), pp. 1-8. Available at: https://www.neliti.com/id/publicati ons/72532/analisis-rasio-keuanganuntuk-menilai-kinerja-keuanganperusahaan

Andre, O. (2010). Pengaruh Profitabilitas, Likuiditas, \& Leverage Dalam Memprediksi Financial Distress (Studi Empiris Pada Perusahaan Aneka Industri yang Terdaftar di BEI Tahun 2006-2010). pp. 293-312. Available at: http://ejournal.unp.ac.id/index.php/ wra/article/view/6146

Andriyani, I. (2015). Pengaruh Rasio Keuangan Terhadap Pertumbuhan Laba Pada Perusahaan Pertambangan Yang Terdaftar Di Bursa Efek Indonesia Ima Andriyani 1', Ima Andriyani, 13(2), pp. 344-358. Available at: https://www.neliti.com/id/publicati ons/283950/pengaruh-rasiokeuangan-terhadap-pertumbuhanlaba-pada-perusahaanpertambangan-y

Anggasari, L. \& Aji, T. S. (2018). Pengaruh Ukuran Perusahaan, Leverage, Likuiditas, Perputaran Modal Kerja dan Pertumbuhan Penjualan Terhadap Profitabilitas (Sektor Industri Barang dan Konsumsi yang Terdaftar di Bursa Efek Indonesia Periode 20132016)', Jurnal Ilmu Manajemen (JIM), 6(4), pp. 542-549. available at:

https://jurnalmahasiswa.unesa.ac.id /index.php/jim/article/view/24799

Aryanti, F., Hardiyanto, A. T. \& Simamora, P. (2017). Pengaruh Struktur Modal, Ukuran Perusahaan, Dan Pertumbuhan
Printed ISSN : $2406-7415$

Electronic ISSN : 2655 - 9919

Jurnal Akuntansi dan Bisnis Krisnadwipayana Volume 8 No. 2 (Mei - Agustus) 2021

Perusahaan Terhadap

Profitabilitas Pada Perusahaan Yang Bergabung Dalam LQ 45 Di Bursa Efek Indonesia Tahun 2013-2015'. available at: https://jom.unpak.ac.id/index.php/ ilmumanajemen/article/view/635

Brigham, E. F. and F.Houston, J. (2013). Dasar-Dasar Manajemen Keuangan. Edited by A. A. Yulianto. Jakarta Selatan. [Diakses 3 April 2020]

Darsono and Ashari. (2005). Pedoman Praktis Memahami Laporan Keuangan. Yogyakarta: CV. Andi Offset. [Diakses 3 April 2020]

Fahmi, I. (2012). Analisis Kinerja Keuangan. Bandung: Alfabeta. [Diakses 3 Arpil 2020]

Fauzi, M. N. and Suhadak. (2015). Pengaruh Kebijakan Deviden \& Pertumbuhan Perusahaan Terhadap Struktur Modal \& Profitabilitas (Studi Pada Sektor Mining yang Terdaftar Di Bursa Efek Indonesia Periode 20112013)', 24(1), pp. 1-10. Available at:

http://administrasibisnis.studentjo urnal.ub.ac.id/index.php/jab/articl e/view/956

Ghozali, I. (2018). Aplikasi Analisis Multivariate dengan Program IBM SPSS 25. Semarang: Badan Penerbit Universitas Diponegoro. [Diakses 3 April 2020]

Gujarati, D. N. (2015). Dasar-Dasar

Ekonometrika. Buku II. 5th edn. Jakarta Selatan: Salemba Empat. [Diakses 3 April 2020]

Hantono, H. (2018). the Effect of Current Ratio, Debt To Equity Ratio, Toward Return on Assets (Case Study on Consumer Goods Company)', Accountability, 7(02), 
DOI: http://dx.doi.org/10.35137/jabk.v8i2.542

p. $64 . \quad$ available at:

10.32400/ja.24804.7.02.2018.64-

73.

Harahap, S. S. (2010). Analisis Kritis Atas

Laporan Keuangan. Jakarta:

Rajawali Persada. [Diakses 3

April 2020]

Hikmatullah, I. (2017). Analisis Pengaruh

Laba Akuntansi, Return On Assets

(ROA) dan Return On Equity

(ROE) (Studi pada Perusahaan

Manufaktur yang Terdaftar di

Bursa Efek Indonesia Tahun 2012

- 2015'. Available at:

http://eprints.iain-

surakarta.ac.id/261/

IAI. (2002). Standar Akuntansi Keuangan.

Jakarta:

Salemba.

[Diakses 2 April 2020]

IAI. (2015). Penyataan Standar Akuntansi

Keuangan. [Diakses 2 April 2020]

Kasmir. (2016). Analisis Laporan Keuangan. Jakarta: Rajawali Pers.

[Diakses 2 April 2020]

Kusumajaya, D. K. O. (2011). Pengaruh

Struktur Modal \& Pertumbuhan

Perusahaan terhadap Profitabilitas

\& Nilai Perusahaan pada

Perusahaan Manufaktur di Bursa

Efek Indonesia. Universitas

Udayana, pp. 1-132. Available at: https://www.academia.edu/76894

18/pengaruh_struktur_modal_dan _pertumbuhan_perusahaan_terhad ap_profitabilitas_dan_nilai_perusa haan_pada_perusahaan_manufakt ur_di_bursa_efek_indonesia

Lely, S. (2019). Pengaruh Likuiditas , Leverage \& Pertumbuhan Perusahaan Terhadap Profitabilitas pada Perusahaan Property dan Real Estate yang Terdaftar di Bursa Efek Indonesia Tahun 2013-2017'. Available at: http://repositori.usu.ac.id/handle/1
Printed ISSN : $2406-7415$

Electronic ISSN : 2655 - 9919

Jurnal Akuntansi dan Bisnis Krisnadwipayana

Volume 8 No. 2 (Mei - Agustus) 2021

$$
\text { 23456789/15957 }
$$

Maith, H. A. (2013). Analisis Laporan Keuangan Dalam Mengukur Kinerja Keuangan Pada Pt. Hanjaya Mandala Sampoerna Tbk.', Jurnal Riset Ekonomi, Manajemen, Bisnis dan Akuntansi, 1(3), pp. 619-628. Available at: https://ejournal.unsrat.ac.id/index. $\mathrm{php} / \mathrm{emba} /$ article/view/2130

Mamduh M., H. and Halim, A. (2009). Analisa Laporan Keuangan. Yogyakarta: UPP STIM YKPN. [Diakses 2 April 2020]

Masita Dewi, D. (2016). Pengaruh Likuiditas, Leverage, Ukuran Perusahaan Terhadap Kebijakan Dividen Tunai Dengan Profitabilitas Sebagai Variabel Intervening', Jurnal Bisnis dan Ekonomi (JBE), 23(1), pp. 12-19. Available at: https://www.unisbank.ac.id/ojs/in dex.php/fe3/article/view/4302

Mufidah, hajar L. and Azizah, D. F. (2018). Pengaruh Rasio Aktivitas \& Rasio Leverage Terhadap Profitabilitas (Studi pada Perusahaan Sub Sektor Food \& Beverages yang terdaftar di BEI Periode 2012-2016). Biometrika, 67(3), pp. 669-674. Available at: http://administrasibisnis.studentjo urnal.ub.ac.id/index.php/jab/articl e/view/2448.

Muktiadji, N. and Kamage, R. (2009). Terhadap Pertumbuhan Perusahaan Studi kasus pada PT . Gudang Garam , Tbk . dan Bentoel Internasional Tbk', 9(1), pp. 38-44. available at: https://jurnal.stiekesatuan.ac.id/in dex.php/jir/article/view/38

Munawir .(2015). Analisis Laporan Keuangan. 4th edn. Yogyakarta: 
DOI: http://dx.doi.org/10.35137/jabk.v8i2.542

Liberty. [Diakses 2 April 2020]

Novyanny, M. C. and Turangan, J. A. (2013). Pengaruh Likuiditas, Ukuran Perusahaan, Umur Perusahaan \& Pertumbuhan Perusahaan Terhadap Profitabilitas Pada Perusahaan Jasa Sektor Perdagangan, Jasa dan Investasi yang Terdaftar Pada Bursa Efek Indonesia'. Available at:

https://journal.untar.ac.id/index.ph p/JMDK/article/view/2790

Nugroho, E. (2011). Analisis Pengaruh Likuiditas, Pertumbuhan Penjualan, Perputaran Modal Kerja, Ukuran Perusahaan \& Leverage Terhadap Profitabilitas Perusahaan (Studi Pada Perusahaan Manufaktur yang Terdaftar Pada BEI Pada Tahun 2005 - 2009). Jurnal Akuntansi, pp. 1-77. Available at: http://eprints.undip.ac.id/29208/

Nugroho, E. and Pangestuti, I. R. D. (2011) 'Analisis Pengaruh Likuiditas, Pertumbuhan Penjualan, Perputaran Modal Kerja, Ukuran Perusahaan \& Leverage Terhadap Profitabilitas Perusahaan', Thesis, pp. 1-30. Available at: http://eprints.undip.ac.id/29208/1/ Jurnal_Elfianto_Nugroho_C2A00 6054.pdf

PA, M. and Dohar, M. (2016). Pengaruh Current Ratio Dan Debt To Equity Ratio Terhadap Return On Assets', Widyakala Journal, 3, p. 23. Available at: doi:10.36262/widyakala.v3i0.21.

Pashah, A., Paramita, P., \& Oemar, A. (2018). Pengaruh Likuiditas, Ukuran Perusahaan, Leverage \& Pertumbuhan Perusahaan
Printed ISSN : $2406-7415$

Electronic ISSN : 2655 - 9919

Jurnal Akuntansi dan Bisnis Krisnadwipayana Volume 8 No. 2 (Mei - Agustus) 2021

Terhadap Profitabilitas Dengan Struktur Modal Sebagai Variabel Intervening Pada Perusahaan Manufaktur Yang Terdaftar Pada BEI Tahun 2012-2016. Journal Of Accounting, pp. 1-20. Available at:

http://jurnal.unpand.ac.id/index.ph p/AKS/article/viewFile/1179/1149

Prasetyo, A. \& Sunarto. (2009). Pengaruh Leverage, Ukuran dan Pertumbuhan Perusahaan Terhadap Profitabilitas. 6. Available at: https://www.unisbank.ac.id/ojs/in dex.php/fe5/article/view/2072

Prastowo, D. (2011). Analisis Laporan Keuangan Konsep Dan Aplikasi. Yogyakarta: STIM YKPN. [Diakses 2 April 2020]

Priharyanto, B. (2009). Analisis Pengaruh Current Ratio Inventory Turnover, Debt to Equity Ratio \& Size Terhadap Profitabilitas. Available at:

https://core.ac.uk/download/pdf/1 1723157.pdf

Putra, A. A. W. Y. \& Badjra, I. B. (2015). Pengaruh Leverage, Pertumbuhan Perusahaan Dan Ukuran Perusahaan Terhadap Profitabilitas', 4(7), pp. 20522067. Available at: https://media.neliti.com/media/pu blications/249411-pengaruhleverage-pertumbuhan-penjualan047f163a.pdf

Putra, Y. Y. D. \& Wiagustini, N. L. P. (2019). Pengaruh Likuiditas \& Leverage Terhadap Profitabilitas \& Nilai Perusahaan Pada Perusahaan Perbankan Di Bei', Jurnal Wawasan Manajemen, 1(2), pp. 215-232. Available at: https://jwm.ulm.ac.id/id/index.php 
DOI: http://dx.doi.org/10.35137/jabk.v8i2.542

/jwm/article/view/47

Putri, Y. T. (2015). Pengaruh Likuiditas,

Leverage, Pertumbuhan Penjualan, \& Perputaran Modal Kerja

Terhadap Profitabilitas'. Available at:

http://repository.unpas.ac.id/5589/

Rahmawati, S., Salim, M. A. \& ABS, M. K. (2016). Pengaruh Likuiditas, Pertumbuhan Penjualan, Perputaran Modal Kerja, Ukuran Perusahaan \& Leverage Terhadap Profitabilitas Perusahaan (Studi pada Perusahaan Manufaktur yang Terdaftar di BEI pada Tahun 2014-2016)', pp. 82-94. Available at:

http://riset.unisma.ac.id/index.php /jrm/article/viewFile/1257/1257

Ramang, G. D. P., Tumbel, T. M. \& Rogahang, J. J. (2019). Analisis Rasio Keuangan Untuk Menilai Kinerja Keuangan pada PT. Indonesia Prima Poperty Tbk Jakarta Pusat', Jurnal Administrasi Bisnis, 9(3), p. 122. Available at: https://ejournal.unsrat.ac.id/index. php/jab/article/view/25543/25195.

Saidi. (2004). Faktor-Faktor yang Mempengaruhi Struktur Modal Pada Perusahaan Manufaktur GoPublic di BEJ Tahun 1997-2002', Bisnis dan Ekonomi. Available at: https://journal.umy.ac.id/index.ph p/ai/article/download/1082/1163

Sartono, A. (2010). Manajemen Keuangan Teori \& Aplikasi. Empat. Yogyakarta. [Diakses 7 April 2020]

Silvia, D. and Sari, M. S. (2018). Pengaruh Likuiditas Terhadap Profitabilitas pada PT . Mustika Ratu, Tbk', pp. 203-210.

Available
Printed ISSN : $2406-7415$

Electronic ISSN : 2655 - 9919

Jurnal Akuntansi dan Bisnis Krisnadwipayana

Volume 8 No. 2 (Mei - Agustus) 2021

https://jurnal.darmajaya.ac.id/index .php/PSND/article/download/1310/ 826

Susanto, H. and Kholis, N. (2016). Analisis Rasio Keuangan terhadap Profitabilitas pada Perbankan Indonesia Financial Ratio Analysis toward Profitability on Indonesian Banking', pp. 11-22. Available at: https://ebbank.stiebbank.ac.id/inde x.php/EBBANK/article/download/ $83 / 84$

Tandelilin, E. (2001). Analisis Investasi Dan Manajemen Portofolio. Yogyakarta: BPFE. [Diakses 3 April 2020]

Tjiptono, D. and Fakhruddin, H. M. (2011). Pasar Modal Di Indonesia. 3rd edn. Jakarta: Salemba Empat. [Diakses 3 April 2020]

Widiastuti, N. A., Arifati, R. and Abrar. (2016). 'Pengaruh Leverage, Ukuran Perusahaan, Pertumbuhan Perusahaan, Rasio Likuiditas, \& Rasio Aktivitas Terhadap Profitabilitas', 2(2). Available at: http://eprints.umm.ac.id/38896/1/1 $\%$.pdf 